University of South Carolina

Scholar Commons

\title{
Protocols for Assessing Transformation Rates of Nitrous Oxide in the Water Column
}

Annie Bourbonnais

University of South Carolina - Columbia, abourbonnais@seoe.sc.edu

Claudia Frey

Xin Sun

Laura A. Bristow

Amal Jayakumar

See next page for additional authors

Follow this and additional works at: https://scholarcommons.sc.edu/geol_facpub

Part of the Biology Commons, and the Marine Biology Commons

\section{Publication Info}

Published in Frontiers in Marine Science, Volume 8, 2021.

(c) 2021 Bourbonnais, Frey, Sun, Bristow, Jayakumar, Ostrom, Casciotti and Ward. This is an open-access article distributed under the terms of the Creative Commons Attribution License (CC BY).

This Article is brought to you by the Earth, Ocean and Environment, School of the at Scholar Commons. It has been accepted for inclusion in Faculty Publications by an authorized administrator of Scholar Commons. For more information, please contact digres@mailbox.sc.edu. 


\section{Author(s)}

Annie Bourbonnais, Claudia Frey, Xin Sun, Laura A. Bristow, Amal Jayakumar, Nathaniel E. Ostrom, Karen L. Casciotti, and Bess B. Ward 


\title{
Protocols for Assessing Transformation Rates of Nitrous Oxide in the Water Column
}

\author{
Annie Bourbonnais ${ }^{1 *}$, Claudia Frey ${ }^{2+}$, Xin Sun 3,4 , Laura A. Bristow ${ }^{5}$, Amal Jayakumar ${ }^{3}$, \\ Nathaniel E. Ostrom ${ }^{6}$, Karen L. Casciotti ${ }^{7}$ and Bess B. Ward ${ }^{3}$ \\ ${ }^{1}$ School of the Earth, Ocean and Environment, University of South Carolina, Columbia, SC, United States, ${ }^{2}$ Department \\ of Environmental Sciences, University of Basel, Basel, Switzerland, ${ }^{3}$ Department of Geosciences, Princeton University, \\ Princeton, NJ, United States, ${ }^{4}$ Department of Ecology and Evolutionary Biology, Yale University, New Haven, CT, \\ United States, ${ }^{5}$ Nordcee, Department of Biology, University of Southern Denmark, Odense, Denmark, ${ }^{6}$ Department \\ of Integrative Biology, Great Lakes Bioenergy Research Center, Michigan State University, East Lansing, MI, United States, \\ ${ }^{7}$ Department of Earth System Science, Stanford University, Stanford, CA, United States
}

OPEN ACCESS

Edited by:

Johannes Karstensen, GEOMAR Helmholtz Center for Ocean Research Kiel, Germany

Reviewed by: Annette Kock, GEOMAR Helmholtz Center for Ocean Research Kiel, Germany Jana Milucka, Max Planck Institute for Marine Microbiology (MPG), Germany

*Correspondence:

Annie Bourbonnais

abourbonnais@seoe.sc.edu

${ }^{\dagger}$ These authors have contributed equally to this work

Specialty section: This article was submitted to

Ocean Observation,

a section of the journal Frontiers in Marine Science

Received: 29 September 2020 Accepted: 05 March 2021 Published: 22 April 2021

Citation: Bourbonnais A, Frey C, Sun X, Bristow LA, Jayakumar $A$,

Ostrom NE, Casciotti KL and Ward BB (2021) Protocols for Assessing Transformation Rates of Nitrous Oxide in the Water Column.

Front. Mar. Sci. 8:611937.

doi: 10.3389/fmars.2021.611937
Nitrous oxide $\left(\mathrm{N}_{2} \mathrm{O}\right)$ is a potent greenhouse gas and an ozone destroying substance. Yet, clear step-by-step protocols to measure $\mathrm{N}_{2} \mathrm{O}$ transformation rates in freshwater and marine environments are still lacking, challenging inter-comparability efforts. Here we present detailed protocols currently used by leading experts in the field to measure water-column $\mathrm{N}_{2} \mathrm{O}$ production and consumption rates in both marine and other aquatic environments. We present example ${ }^{15} \mathrm{~N}$-tracer incubation experiments in marine environments as well as templates to calculate both $\mathrm{N}_{2} \mathrm{O}$ production and consumption rates. We discuss important considerations and recommendations regarding (1) precautions to prevent oxygen $\left(\mathrm{O}_{2}\right)$ contamination during low-oxygen and anoxic incubations, (2) preferred bottles and stoppers, (3) procedures for ${ }^{15} \mathrm{~N}$ tracer addition, and (4) the choice of a fixative. We finally discuss data reporting and archiving. We expect these protocols will make ${ }^{15} \mathrm{~N}$-labeled $\mathrm{N}_{2} \mathrm{O}$ transformation rate measurements more accessible to the wider community and facilitate future inter-comparison between different laboratories.

Keywords: nitrous oxide, ${ }^{15} \mathrm{~N}$-tracer incubations, production, consumption, rates, water-column, greenhouse gas

\section{INTRODUCTION}

Nitrous oxide $\left(\mathrm{N}_{2} \mathrm{O}\right)$ is a greenhouse gas with a 300 times higher warming potential than carbon dioxide (Myhre et al., 2013) as well as the dominant stratospheric ozone-depleting substance (Nevison and Holland, 1997; Ravishankara et al., 2009). One third of global natural $\mathrm{N}_{2} \mathrm{O}$ emissions to the atmosphere are from marine environments, yet $\mathrm{N}_{2} \mathrm{O}$ production and consumption in productive coastal waters are still not well quantified (e.g., Nevison et al., 2004). It is also unclear how $\mathrm{N}_{2} \mathrm{O}$ cycling will respond to ongoing expansion of marine oxygen $\left(\mathrm{O}_{2}\right)$ deficient zones (Stramma et al., 2008) and climate change.

$\mathrm{N}_{2} \mathrm{O}$ production rates are estimated by tracking the transformation of a ${ }^{15} \mathrm{~N}$-labeled substrate $\left({ }^{15} \mathrm{~N}_{-} \mathrm{NH}_{4}{ }^{+},{ }^{15} \mathrm{~N}_{-} \mathrm{NO}_{2}{ }^{-}\right.$, or $\left.{ }^{15} \mathrm{~N}^{-\mathrm{NO}_{3}}{ }^{-}\right)$to the $\mathrm{N}_{2} \mathrm{O}$ product. $\mathrm{N}_{2} \mathrm{O}$ is produced by aerobic nitrification [by either hydroxylamine oxidation, nitrifier-denitrification or a hybrid mechanism (Trimmer et al., 2016; Stein, 2019)] or denitrification under low- $\mathrm{O}_{2}$ conditions. $\mathrm{N}_{2} \mathrm{O}$ 
consumption rates are estimated by tracking the transformation of ${ }^{15} \mathrm{~N}$-labeled $\mathrm{N}_{2} \mathrm{O}$ to the $\mathrm{N}_{2}$ product under anaerobic conditions (Figure 1). $\mathrm{N}_{2} \mathrm{O}$ production during water-column denitrification is mostly performed by prokaryotic microbes (Prosser et al., 2020). However, eukaryotes (such as fungi, protists, benthic foraminifera, and gromids) also contribute to $\mathrm{N}_{2} \mathrm{O}$ production in sediments and soils (Piña-Ochoa et al., 2010; Huang et al., 2017), but their roles in water-column processes remains to be confirmed. Fungi have been specifically proposed to be involved in the generation of hybrid $\mathrm{N}_{2} \mathrm{O}$ (Shoun et al., 2012).

Despite the urgent need to better constrain $\mathrm{N}_{2} \mathrm{O}$ transformations in both marine and freshwater systems, clear step-by-step protocols are lacking. This issue was recently raised during the "Oceanic Methane and Nitrous Oxide Workshop: The present situation and future scenarios!" at Lake Arrowhead in October 2018 (Wilson et al., 2020), motivating the writing of standard operating procedures that would facilitate future inter-comparison efforts between different laboratories.

The Lake Arrowhead workshop was instrumental in connecting us with people with relevant expertise in the field. Researchers with relevant expertise were contacted and invited to contribute to this manuscript. We also reviewed current literature using ${ }^{15} \mathrm{~N}$-labeled compounds to measure $\mathrm{N}_{2} \mathrm{O}$ production and consumption rates to get an overview of existing techniques. As part of this process, we realized that the methodologies used are influenced by several factors, such as specific research questions, studied ecosystems, or available analytical equipment. Hence, we concluded that there is not one "best method," but several acceptable methods, with generally only slight procedural differences. Finally, we present techniques used by six laboratories working in freshwater and marine environments (Michigan State University, Princeton University, Stanford University, University of Basel, University of South Carolina and University of

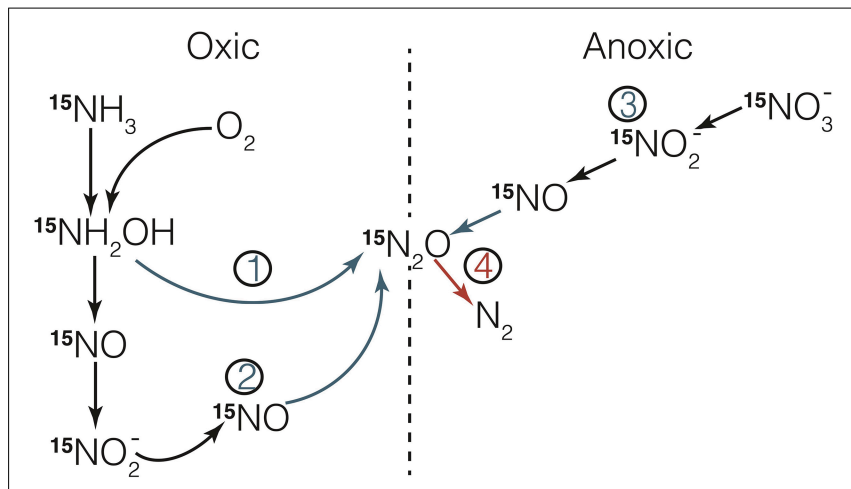

FIGURE 1 | Processes producing (in blue) and consuming (in red) $\mathrm{N}_{2} \mathrm{O}$ in the water-column. $\mathrm{N}_{2} \mathrm{O}$ is produced from hydroxylamine oxidation (1) or nitrifier-denitrification (2) under oxic or low- $\mathrm{O}_{2}$ conditions. Under low- $\mathrm{O}_{2}$ or anoxic conditions, $\mathrm{N}_{2} \mathrm{O}$ is produced by denitrification (3). $\mathrm{N}_{2} \mathrm{O}$ consumption (4) only occurs during denitrification under anoxic conditions. In the water-column, all these processes are primarily mediated by ammonia-oxidizing microbes and denitrifying bacteria. Figure 2 shows $\mathrm{N}_{2} \mathrm{O}$ production by a hybrid mechanism as suggested during archaeal ammonia oxidation (Kozlowski et al., 2016).
Southern Denmark). A draft of this manuscript was also disseminated to the broader scientific community before publication, including experts who could not attend the Lake Arrowhead workshop. Our goal is to provide detailed and community-reviewed protocols to measure watercolumn $\mathrm{N}_{2} \mathrm{O}$ production and consumption rates using ${ }^{15} \mathrm{~N}$-tracer incubations in marine and freshwater environments. This synthesis is indispensable for new researchers trying to reproduce these experiments but also represents the first step toward a thorough inter-comparison of these protocols between labs.

\section{MATERIALS AND METHODS}

The following section will explain the workflow protocols for $\mathrm{N}_{2} \mathrm{O}$ production (Part A) and $\mathrm{N}_{2} \mathrm{O}$ consumption (Part B) in detail. Part $\mathrm{B}$ is further divided into methods \#1 and \#2.

\section{Part A: $\mathrm{N}_{2} \mathrm{O}$ Production During Aerobic Nitrification and Denitrification}

Different treatments are used to measure $\mathrm{N}_{2} \mathrm{O}$ production during aerobic nitrification (Table 1 and Figures 1, 2). Figure 3 shows the workflow for ${ }^{15} \mathrm{~N}-\mathrm{NH}_{4}{ }^{+}$incubation experiments, which could be done with or without a headspace. The same workflow would apply for ${ }^{15} \mathrm{~N}-\mathrm{NO}_{2}{ }^{-}$incubations and experiments targeting denitrification $\left({ }^{15} \mathrm{~N}-\mathrm{NO}_{3}{ }^{-}\right)$. Adding a headspace is strongly recommended if $\mathrm{O}_{2}$ concentrations are to be manipulated during the incubations, by either purging the liquid phase with inert gas to remove remnant $\mathrm{O}_{2}$ or by adding $\mathrm{O}_{2}$ (Ji et al., 2015; Frame et al., 2017) via additions of air saturated in situ seawater, air or pure $\mathrm{O}_{2}$ gas. Different $\mathrm{O}_{2}$ treatments should be implemented immediately after creating a headspace. It is also practical to add a headspace if samples are degassed directly from the bottle during Isotope Ratio Mass Spectrometer (IRMS) analysis (e.g., Ji et al., 2015). If $\mathrm{O}_{2}$ manipulations or anoxic experiments are performed (Figure 3A), purging the liquid phase (to remove $\mathrm{O}_{2}$ ) will also remove in situ $\mathrm{N}_{2} \mathrm{O}$. Thus the addition of $\mathrm{N}_{2} \mathrm{O}$ at natural abundance is highly recommended to increase $\mathrm{N}_{2} \mathrm{O}$ concentrations above the detection limit of GCIRMS (typically 1-5 nmol). However, no headspace is necessary if the $\mathrm{O}_{2}$ concentrations are not manipulated for the different treatments and if seawater is first transferred from the bottle to an extractor and then degassed before purge and trap and IRMS analysis following the protocols by McIlvin and Casciotti (2010) or Bourbonnais et al. (2017).

TABLE 1 | Different ${ }^{15} \mathrm{~N}$-labeled substrate additions to measure $\mathrm{N}_{2} \mathrm{O}$ production during aerobic nitrification and denitrification.

\begin{tabular}{lc}
\hline Process & Treatment \\
\hline Hydroxylamine oxidation & ${ }^{15} \mathrm{~N}-\mathrm{NH}_{4}{ }^{+}$ \\
Nitrifier-denitrification & ${ }^{15} \mathrm{~N}-\mathrm{NO}_{2}{ }^{-}$ \\
Hybrid & ${ }^{15}{\mathrm{~N}-\mathrm{NH}_{4}+}^{+}+{ }^{14}{\mathrm{~N}-\mathrm{NO}_{2}-}^{-}$or ${ }^{15} \mathrm{~N}-\mathrm{NO}_{2}{ }^{-}+{ }^{14} \mathrm{~N}_{-} \mathrm{NH}_{4}{ }^{+}$ \\
Denitrification & ${ }^{15} \mathrm{~N}_{-\mathrm{NO}_{2}}-$ or ${ }^{15} \mathrm{~N}-\mathrm{NO}_{3}{ }^{-}$
\end{tabular}




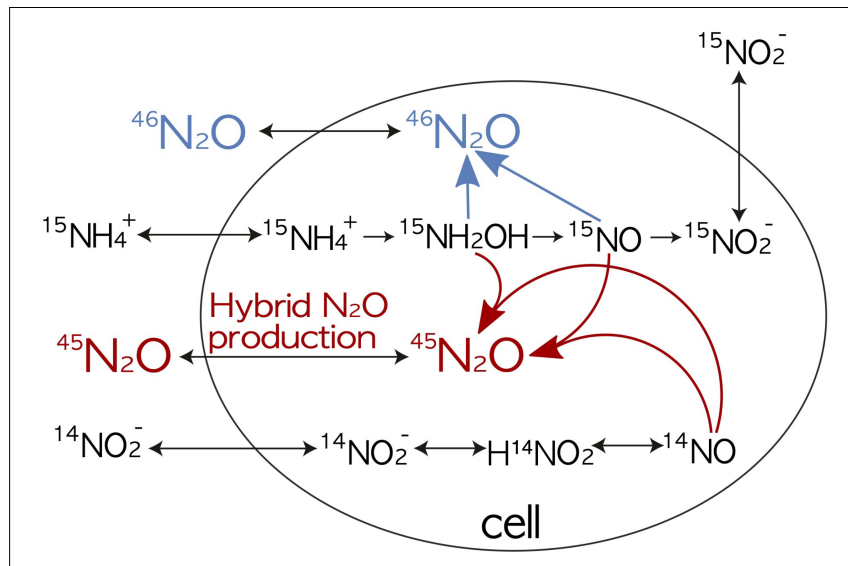

FIGURE 2 | Production of ${ }^{46} \mathrm{~N}_{2} \mathrm{O}$ and ${ }^{45} \mathrm{~N}_{2} \mathrm{O}$ during ${ }^{15} \mathrm{~N}$-labeled incubations with ${ }^{15} \mathrm{~N}-\mathrm{NH}_{4}{ }^{+}$or ${ }^{15} \mathrm{~N}-\mathrm{NO}_{2}{ }^{-}$(Table 1), focusing on hybrid $\mathrm{N}_{2} \mathrm{O}$ production. Modified from Frey et al. (2020).

\section{Supplies}

Note: Items that can be substituted by other brands are marked with a ${ }^{*}$.

\section{Chemicals/Gases}

- ${ }^{15} \mathrm{~N}$ tracer (>98\%): $\mathrm{NH}_{4} \mathrm{Cl}\left(98.5 \%{ }^{15} \mathrm{~N}\right), \mathrm{NaNO}_{2}(99.2 \%$

${ }^{15} \mathrm{~N}$ ), and $\mathrm{NaNO}_{3}\left(98.5 \%{ }^{15} \mathrm{~N}\right)$ salts* (NLM-467, NLM-658, and NLM-157, Cambridge Isotope Laboratories)

- Non-labeled $\mathrm{NH}_{4} \mathrm{Cl}$ and $\mathrm{NaNO}_{2}$ salts

- Solutions of saturated $\mathrm{HgCl}_{2}$ or $50 \% \mathrm{w} / \mathrm{v} \mathrm{ZnCl}_{2}$
- He and $\mathrm{N}_{2}$ tanks (UHP 5.0 to 4.6 grade) for purging the liquid phase

- 1,000 ppm $\mathrm{N}_{2} \mathrm{O}$ gas at natural abundance (add only if purging the liquid phase - see section "Purging the Liquid Phase With He or $\mathrm{N}_{2}$ Gas")

- $\mathrm{O}_{2}$ (UHP, 4.4 grade) gas for $\mathrm{O}_{2}$ manipulation experiments

\section{Other Supplies}

- Serum glass bottles (60-125 mL) with a $20 \mathrm{~mm}$ opening diameter [Wheaton \#223746 (60 $\mathrm{mL})$ or \#223748 $(125 \mathrm{~mL})]^{*}$

Note: The volume of the bottles reported by the vendor differs from the actual volume as it does not include the neck of the bottle. For instance, the measured volume for the $125 \mathrm{~mL}$ bottles is about $160 \mathrm{~mL}$.

- $1 \mathrm{M} \mathrm{HCl}$ acid bath

- MilliQ water supply

- Muffle furnace

- Disposable gloves

- Plastic volumetric flasks, pipettes and pipette tips to prepare ${ }^{15} \mathrm{~N}$-tracer solution at sea

- Glass beads (about $1 \mathrm{~mm}$ diameter)

Note: These are only needed for headspace-free incubations.

- Tygon tubing (approximately $1 \mathrm{~m}$ length) with adaptors to fit the Niskin bottle opening

- Gray butyl septa (20 mm) (Wheaton \#20-0025)

- Aluminum crimp seals (20 mm) (Wheaton \#224178-01)

- Crimper for $20 \mathrm{~mm}$ cap

- Decrimper for $20 \mathrm{~mm}$ caps

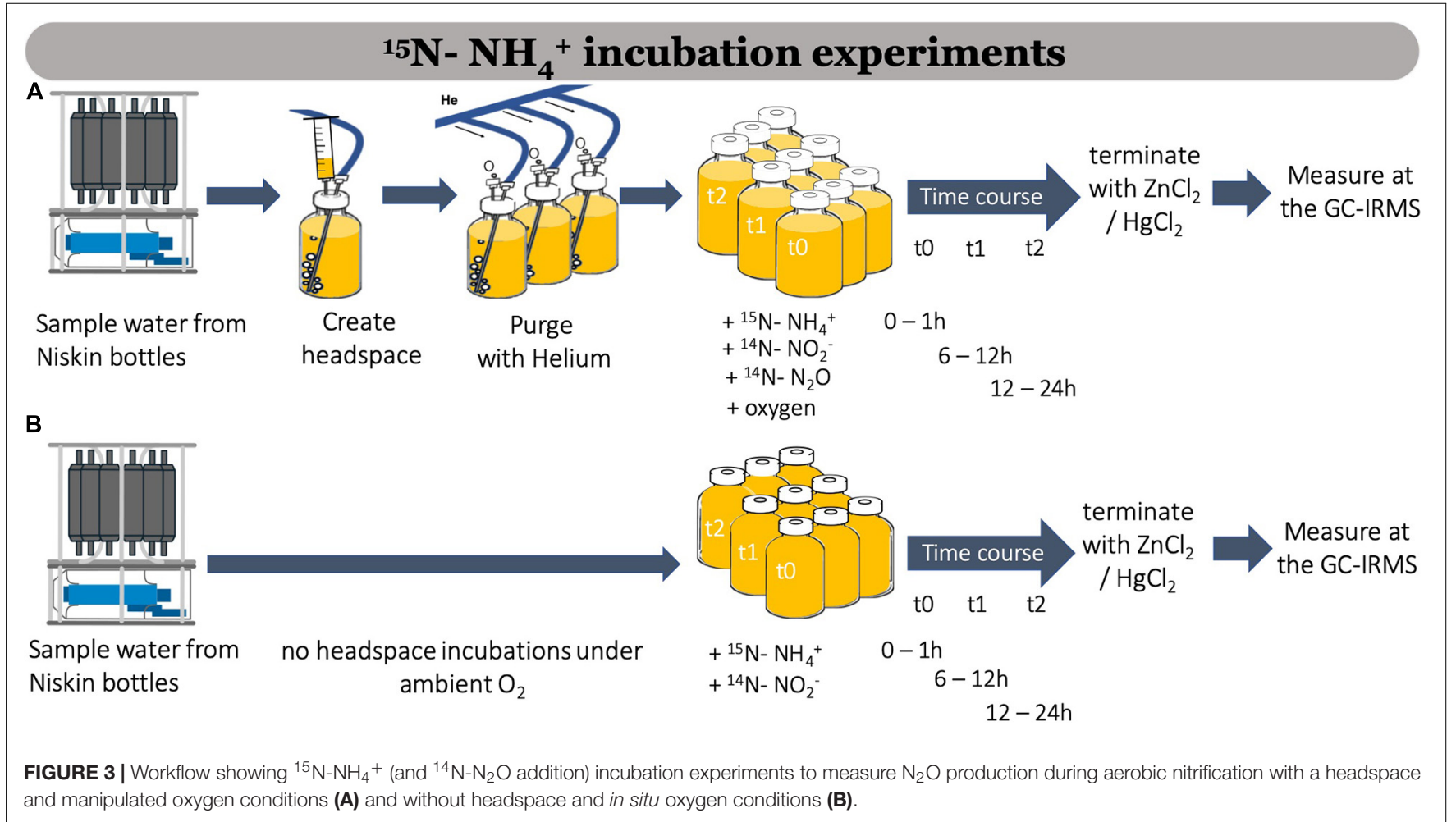


- Plastic container to hold bottles during sampling

- Various size luer-lock gas tight glass syringes for liquid tracer addition* (e.g., $1 \mathrm{~mL}$ Hamilton gastight syringe model 1001 TLL, \#81320; $100 \mu \mathrm{L}$ gastight syringe model 1710 TLL, \#81020) with a $25 \mathrm{G}$ or $23 \mathrm{G}$ regular bevel needle

- Non-gas-tight syringes*, e.g., BD luer-lock tip $1 \mathrm{~mL}$ (\#309628), $3 \mathrm{~mL}$ (\#309657), $5 \mathrm{~mL}$ (\#309646), $10 \mathrm{~mL}$ (\#309604), and $50 \mathrm{~mL}$ (\#309653)

- Various size needles*: BD PrecisionGlide Regular Bevel needles, e.g., $25 \mathrm{G} \times 5 / 8^{\prime \prime}(\# 305122)$ or $23 \mathrm{G} \times 3 / 4^{\prime \prime}(\mathrm{BD}$ $\# 305143)$ and $25 \mathrm{G} \times 11 / 2^{\prime \prime}(\# 305127)$ or $23 \mathrm{G} \times 11 / 4^{\prime \prime}(\mathrm{BD}$ \#305120) to inject isotopic tracers and $\mathrm{HgCl}_{2}$

- 18G, 6" stainless steel needle* (that reaches the bottom of the bottle) for purging the liquid phase (e.g., Cadence science \#9860) or $21 \mathrm{G} \times 43 / 4^{\prime \prime}$ (B Braun \#4665643) (depending on bottle size)

- Purging rack with Viton tubing* (e.g., 1/16" ID × 1/8" OD, Fisher Scientific, \#NC0511742) and Swagelok unions for purging liquid phase

- Dual stage regulators, stainless steel or brass tubing, Swagelok fittings, and mechanical flow controller (e.g., Porter, VCD-1000) for purging and gas transfer

- Fixed needle gastight glass syringes to inject gases*: i.e., Hamilton, sample lock: $1 \mathrm{~mL}$ (\#81356), $500 \mu \mathrm{L}$ (\#81256), $250 \mu \mathrm{L}$ (\#81156), and $100 \mu \mathrm{L}$ (\#81056)

- Incubator (or temperature-controlled room or container) covering the in situ temperature range of the samples

- $\mathrm{O}_{2}$ probe/meter and oxygen sensor spots (Oxysense, Pyroscience, or custom-made sensor spots as in Larsen et al., 2016) for $\mathrm{O}_{2}$ monitoring during incubations

- $25 \mathrm{~mm}$ polycarbonate (Whatman nucleopore, $0.45 \mu \mathrm{m}$ ) or GF/F (Whatman, $0.7 \mu \mathrm{m}$ ) filters* (e.g., Fisher Scientific \#09-874-64)

- Acid-washed syringe filter holder for filtration* (e.g., Pall pressure syringe filter holder: \#246800, Hach)

- Acid washed 15-50 mL Falcon conical tubes or high density polyethylene (HDPE) bottles to store filtered aliquots for nutrient and isotope analysis

- IRMS adapted for $\mathrm{N}_{2} \mathrm{O}$ isotope measurements (see McIlvin and Casciotti, 2010)

- colored tape and Sharpies for sample labeling

- Notebook, log sheets, and pens

\section{Preparation Before the Sampling Expedition}

\section{Acid Wash All Glassware.}

Prepare ${ }^{15} \mathrm{~N}$ Tracer and Non-labeled Salts. Pre-weigh ${ }^{15} \mathrm{~N}$ tracer and non-labeled salts and store in acid washed small glass vials with screw caps. Label properly. Fresh solution will be prepared in the field.

Build Purging Rack. We recommend building a purging rack using Viton tubing and Swagelok unions, similar to the racks shown in part B, method \#2 below.

Degas the Butyl Stoppers and Caps. Stoppers are degassed by boiling them in purified water for $5 \mathrm{~min}$ and stored under vacuum or He (see De Brabandere et al., 2012).
Transfer Natural Abundance $\mathrm{N}_{2} \mathrm{O}$ and $\mathrm{O}_{2}$ Gases. It is strongly recommended to transfer $\mathrm{N}_{2} \mathrm{O}$ and $\mathrm{O}_{2}$ gases in to several $20 \mathrm{~mL}$ glass vials capped with butyl septa and aluminum crimp seals to avoid unnecessarily shipping gas tanks to research vessels. This should be done just before shipping materials to the ship.

\section{Sample Collection}

Wheaton glass serum bottles should be acid-washed, rinsed with MilliQ water, and heated for at least $4 \mathrm{~h}$ at $500^{\circ} \mathrm{C}$ before sample collection, to remove any organic material. Note that bottle size varies among protocols, ranging from $60 \mathrm{~mL}$ (Ji et al., 2015) to $160 \mathrm{~mL}$ (Frame et al., 2017; Figure 4A). The ideal bottle size should be selected based on the $\mathrm{N}_{2} \mathrm{O}$ detection limit of the IRMS to be used for analysis.

Sample collection is done using the same procedure as for $\mathrm{N}_{2} \mathrm{O}$ concentrations (see Wilson et al. (2018) for more detail). Briefly, each $160 \mathrm{~mL}$ glass serum bottle is filled from a Niskin bottle or pump profiling system using Tygon tubing, which is inserted all the way to the bottom of the bottle and allowed to overflow the bottle volume several times. The flow from the Niskin bottle must be reduced while filling the bottles to avoid splashing. After filling, the bottle is capped, bubble-free, with a gray butyl stopper and aluminum seal.

For headspace-free incubations, a small glass bead $(1 \mathrm{~mm}$ diameter) is added to the glass serum bottles before sampling as it facilitates mixing of the tracer at the start and preservative at the end of the incubations.

For measurement of $\mathrm{N}_{2} \mathrm{O}$ production via aerobic nitrification, some protocols call for sampling water from the Niskin bottles directly into bigger containers if $\mathrm{O}_{2}$ contamination is not an issue (e.g., 3-10 L LDPE or HDPE containers; Frame et al., 2017). Subsampling is then done into glass serum bottles after ${ }^{15} \mathrm{~N}$-tracer addition. This method has the advantage of homogenizing the seawater as well as the added ${ }^{15} \mathrm{~N}$ tracer for each treatment, thus decreasing the standard deviation of replicate measurements. The disadvantage is, that this procedure introduces $\mathrm{O}_{2}$ into the samples and should not be used in low$\mathrm{O}_{2}$ environments.

Since seawater samples are not filtered, some particles may be contained within incubation bottles. However, it is unclear from studies conducted to date if particle associated activity is adequately accounted for during the incubations (Ganesh et al., 2014; Fuchsman et al., 2017).

Sufficient numbers of bottles should be filled at each station and depth to enable at least duplicate measurements of each treatment and time point (see section "Incubation" below).

Record metadata, such as Niskin bottle sampled, depth, location, as well as a few basic data (salinity, temperature, time bottle closed) in order to be able to directly link these samples to databases of hydrographic data from the sampling expedition in repositories such as BCO-DMO (Biological and Chemical Oceanography Data Management Office). In addition to metadata, samples should be collected from all incubation depths for measurements of relevant geochemical (and microbiological) parameters of the sampled water (see section "Data Reporting and Archiving"). 

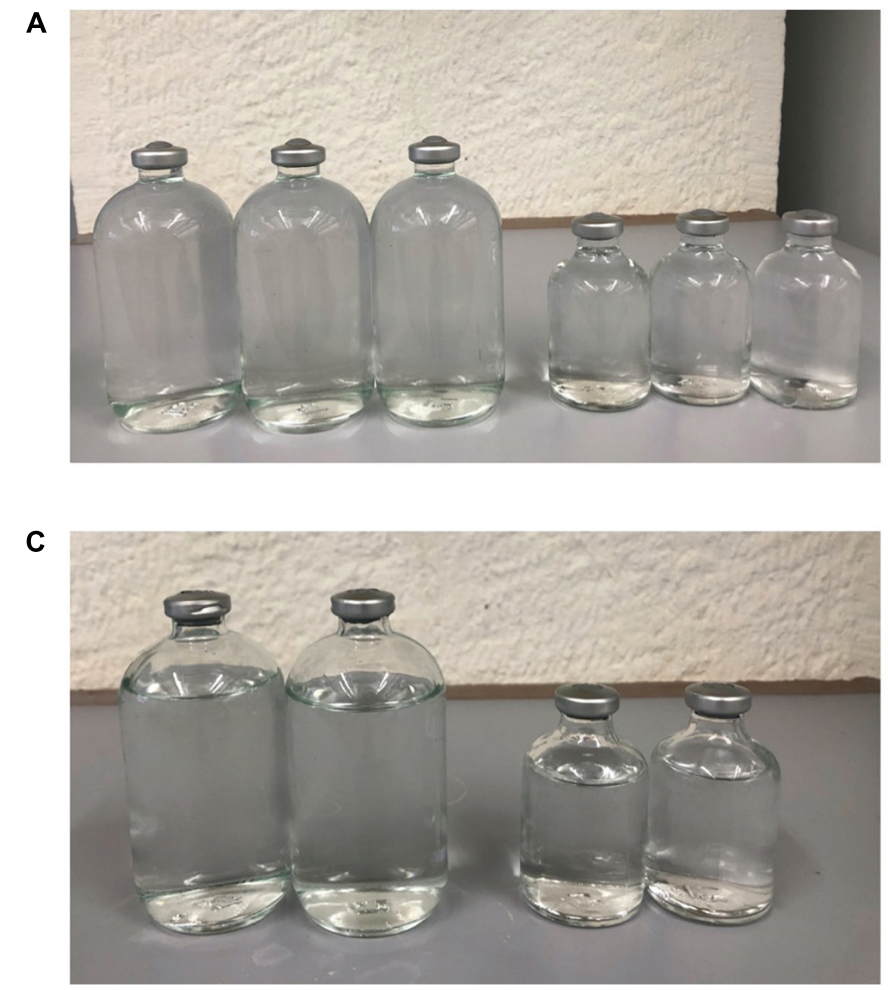

B

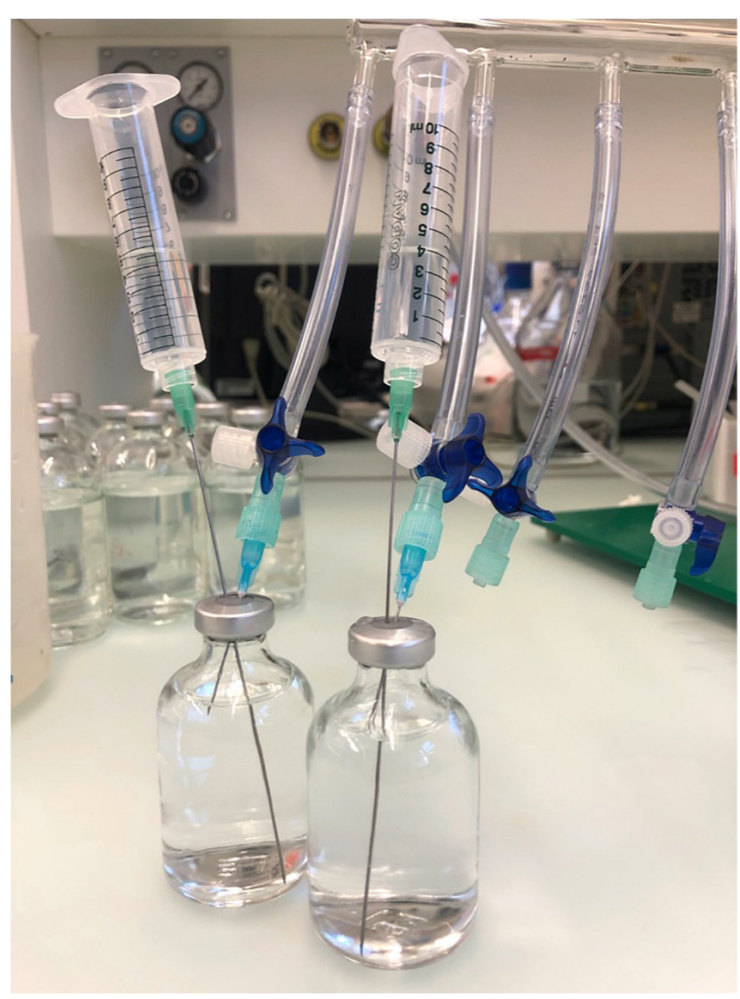

FIGURE 4 | Headspace-free filled 160 and $60 \mathrm{~mL}$ glass serum bottles (A), creating a headspace with a low He flow (up to $10 \mathrm{~mL} / \mathrm{min}$ ) (B), and $20 \mathrm{~mL}$ headspace in $160 \mathrm{~mL}$ serum bottles (12.5\% headspace) and $5 \mathrm{~mL}$ headspace in $60 \mathrm{~mL}$ serum bottles (8\% headspace) (C).

\section{Headspace Introduction}

If $\mathrm{O}_{2}$ concentrations need to be controlled during treatments, a $\mathrm{He}$ or $\mathrm{N}_{2}$ headspace (5-25\% of the bottle volume) is created (Figures 4B,C), e.g., 3-10 mL for $60 \mathrm{~mL}$ bottles (Ji et al., 2015) or 10-40 mL for $160 \mathrm{~mL}$ bottles (Frame et al., 2017). However, in fully oxygenated waters a He headspace can lead to a drawdown of $\mathrm{O}_{2}$ due to diffusion from the liquid into the headspace. Hence, in oxygenated waters an air headspace is preferable. The headspace is added by either flushing a $5 \mathrm{~mL}$ or $60 \mathrm{~mL}$ syringe several times with $\mathrm{He}$ before injecting the desired amount of $\mathrm{He}$ or $\mathrm{N}_{2}$ in the bottles using a $23 \mathrm{G} \times 11 / 2^{\prime \prime}$ needle and a vent needle $\left(23 \mathrm{G} \times 3 / 4^{\prime \prime}\right)$ or by directly adding $\mathrm{He}$ or $\mathrm{N}_{2}$ gas with a low flow (up to $10 \mathrm{~mL} / \mathrm{min}$ ) using a long needle $\left(23 \mathrm{G} \times 11 / 2^{\prime \prime}\right)$ attached to a 10 or $50 \mathrm{~mL}$ syringe as the outlet (Figure 4B).

\section{Purging the Liquid Phase With $\mathrm{He}$ or $\mathrm{N}_{2}$ Gas}

For incubations of anoxic waters or $\mathrm{O}_{2}$ manipulation experiments, purging the liquid phase with $\mathrm{He}$ or $\mathrm{N}_{2}$ gas prior to incubations is strongly recommended. In situ $\mathrm{N}_{2} \mathrm{O}$ is also completely removed during this process if the volume of the serum bottles or exetainers is exchanged 100-times (Frey et al., 2020). In most systems, $\mathrm{N}_{2} \mathrm{O}$ production rates are not high enough to produce sufficient $\mathrm{N}_{2} \mathrm{O}$ over a 24-h incubation to be above detection limit of GC-IRMS analysis (typically 1-5 nmol). $\mathrm{N}_{2} \mathrm{O}$ consumption could further reduce $\mathrm{N}_{2} \mathrm{O}$ concentrations in incubations of anoxic waters. If samples are purged, a non-labeled (i.e., at natural abundance) $\mathrm{N}_{2} \mathrm{O}$ carrier gas should be added back into the serum bottles to (1) lower the ${ }^{15} \mathrm{~N}$ enrichment to be within the range that can be measured by the mass spectrometer and (2) to assure sufficient quantities of $\mathrm{N}_{2} \mathrm{O}$ for analysis on the IRMS.

For incubations of anoxic waters or $\mathrm{O}_{2}$ manipulation experiments, it is highly preferable to purge the liquid phase to remove $\mathrm{O}_{2}$ introduced during sampling. For anoxic incubations, $60 \mathrm{~mL}$ bottles are purged with a $\mathrm{He}$ flow of $0.4 \mathrm{~L} / \mathrm{min}$ for $15 \mathrm{~min}$, exchanging the volume 100-times. $160 \mathrm{~mL}$ serum bottles should be purged for $30 \mathrm{~min}$ at a He flow of $0.6 \mathrm{~L} / \mathrm{min}$. If a different flow or bottle size is used, the length of purging the liquid phase should be tested with an $\mathrm{O}_{2}$ optode and should be adjusted accordingly. For anoxic incubations, $\mathrm{O}_{2}$ should be removed as $\mathrm{O}_{2}$ in the nanomolar range has been shown to influence $\mathrm{N}_{2} \mathrm{O}$ production and consumption rates (Dalsgaard et al., 2014). Inflow needle should reach to the bottom of the serum bottle, vent needle only needs to reach into the headspace. Although not always possible, it is preferable to do all these manipulations under in situ conditions i.e., in situ temperature, and under red light (if the samples were collected from below the euphotic zone).

Add natural abundance $\mathrm{N}_{2} \mathrm{O}$ to the samples. The amount of natural abundance $\mathrm{N}_{2} \mathrm{O}$ added should be calculated based on detection limit of the IRMS. The amount of $\mathrm{N}_{2} \mathrm{O}$ will thus need to be adjusted for bigger bottles (or smaller exetainers) and also depends on headspace volume. For instance, $100 \mu \mathrm{L}$ of 1,000 ppm $\mathrm{N}_{2} \mathrm{O}$ (in $\mathrm{He}$ ) for a final concentration of $20 \mathrm{nmol} / \mathrm{L} \mathrm{N}_{2} \mathrm{O}$ in the 
liquid phase is added in $60 \mathrm{~mL}$ serum bottles [57 $\mathrm{mL}$ liquid and $3 \mathrm{~mL}$ headspace, based on equilibrium concentration calculated using the Weiss and Price (1980) solubility equation]. A $0.5 \mathrm{~mL}$ fixed needle glass syringe with a $23 \mathrm{G}$ regular bevel needle is flushed two times with the 1,000 ppm $\mathrm{N}_{2} \mathrm{O}$ (in $\mathrm{He}$ ) and then $100 \mu \mathrm{L}$ of the gas is added into the liquid phase of the sample. Confirmation that the gas is successfully injected, and the needle is not clogged, can be obtained by visual observation of bubbling. Shake the bottle to obtain homogenization.

\section{${ }^{15} \mathrm{~N}-$ Tracer Addition}

The ${ }^{15} \mathrm{~N}$ tracer should be degassed with $\mathrm{He}$ or $\mathrm{N}_{2}$ gas before being added directly to glass serum bottles. Tracer is added to each incubation bottle using a glass gas tight syringe $(50 \mu \mathrm{L}$ to $1 \mathrm{~mL}$ ) flushed several times with He. A small needle gauge (e.g., $25 \mathrm{G}$ or $23 \mathrm{G} \times 11 / 2^{\prime \prime}$ ) is preferred to preserve septa integrity. A vent needle $\left(23 \mathrm{G} \times 3 / 4^{\prime \prime}\right)$ attached to a $5 \mathrm{~mL}$ syringe (plunger removed) filled with seawater is used during tracer addition if incubated without a headspace. It is preferable to use a vent needle even for small volume additions of tracer $(<100 \mu \mathrm{L})$ to ensure reproducible tracer additions. The needle used for ${ }^{15} \mathrm{~N}$ tracer additions should be longer than the vent needle such that the added tracer is not lost through the vent. Shake the bottle to obtain homogenization.

At least one bottle per treatment should be immediately sacrificed upon addition of the tracer for each treatment to correct for abiotic labeled $\mathrm{N}_{2} \mathrm{O}$ production $(T=0)$, if any, due to preservative addition and storage (e.g., see Ostrom et al., 2016). This sample is also important for determining the fraction of ${ }^{15} \mathrm{~N}$-labeled substrate at the start of the experiment.

\section{Incubation}

Replicate (preferably triplicate) samples per time point amended with each ${ }^{15} \mathrm{~N}$-tracer should be incubated at in situ temperature and light level using at least three time points for up to a $48 \mathrm{~h}$ period. Incubating for more than $48 \mathrm{~h}$ is generally not recommended as it is likely to result in significant changes to the microbial community and activity known as "bottle effects" (Garcia-Robledo et al., 2016).

Ideally, the concentration of $\mathrm{O}_{2}$ in the bottle is monitored over time during the incubation using non-invasive $\mathrm{O}_{2}$ measurement technology, such as Oxysense ${ }^{1}$, Pyroscience ${ }^{2}$ or custom-made sensors (e.g., see Larsen et al., 2016). A sensor dot is attached inside the bottle prior to filling, to ensure that the sensor dot is located in the liquid phase. After injecting the tracer, the $\mathrm{O}_{2}$ concentration is measured continuously using a fiber optic pen. This step is especially important during $\mathrm{O}_{2}$-sensitive treatments. Separate bottles (at least one per treatment) should be used for $\mathrm{O}_{2}$ monitoring. The lower detection limit is generally $>60 \mathrm{nmol}$ $\mathrm{L}^{-1} \quad \mathrm{O}_{2}$ for the Oxysense and Pyroscience sensors but the custom-made trace sensor described in Larsen et al. (2016) measure $\mathrm{O}_{2}$ concentrations as low as $\sim 5 \mathrm{nmol} \mathrm{L}{ }^{-1}$. A lower detection limit (nmol range) is preferable since oxygen at nanomolar levels has been shown to influence denitrification rates (Dalsgaard et al., 2014).

${ }^{1}$ http://www.oxysense.com/

${ }^{2}$ http://www.pyroscience.com/

\section{Termination and Storage}

In order to analyze the production rate of other dissolved nitrogen compounds from the same incubation bottle (i.e., in ${ }^{15} \mathrm{NH}_{4}{ }^{+}$treatments, ${ }^{15} \mathrm{NO}_{2}{ }^{-}$production rates can be determined in the same time course bottles as the $\mathrm{N}_{2} \mathrm{O}$ production rates), two strategies can be applied. The first one is, that before preserving the sample, $10-40 \mathrm{~mL}$ (depending on bottle size) should be withdrawn from at least one bottle per time point for each treatment using a 10 or $50 \mathrm{~mL}$ syringe with a $25 \mathrm{G}$ needle, filtered using polycarbonate membrane or GF/F filters, and stored at $-20^{\circ} \mathrm{C}$. The volume removed should be replaced with $\mathrm{He}$ or $\mathrm{N}_{2}$. The second option is, that no sample is taken prior to fixation and the dissolved fractions are analyzed after the gaseous components are measured. Fixation agents $\left(\mathrm{HgCl}_{2}, \mathrm{ZnCl}_{2}\right)$ do not interfere with NOx box measurements (see Braman and Hendrix, 1989) nor the denitrifier and azide methods (Sigman et al., 2001; McIlvin and Altabet, 2005; Weigand et al., 2016). Concentration and isotopic composition measurements of dissolved inorganic nitrogen $\left({ }^{15} \mathrm{~N}\right.$-labeled $\mathrm{NH}_{4}{ }^{+}, \mathrm{NO}_{2}{ }^{-}$, and $\left.\mathrm{NO}_{3}{ }^{-}\right)$are needed to assess the labeled fraction of ${ }^{15} \mathrm{~N}$-tracer substrates used in the calculation of $\mathrm{N}_{2} \mathrm{O}$ production rates from each substrate (see calculation templates in the Supplementary Material), and can be used to assess ammonium oxidation, nitrite oxidation or nitrate reduction rates in parallel.

Samples are preserved by adding $0.1 \mathrm{~mL}$ of five times diluted saturated solution of $\mathrm{HgCl}_{2}$ or $50 \%$ (w/v) $\mathrm{ZnCl}_{2}$ to each bottle with a $1 \mathrm{~mL}$ plastic syringe to arrest microbial activity. Diluting the $\mathrm{HgCl}_{2}$ saturated solution reduces the toxicity of the hazardous wastes without any impact on sample preservation (e.g., see Bourbonnais et al., 2017; Casciotti et al., 2018). Important considerations: $\mathrm{ZnCl}_{2}$ should not be used for ${ }^{15} \mathrm{NO}_{2}{ }^{-}$incubations because it triggers abiotic $\mathrm{N}_{2} \mathrm{O}$ production. It should also be noted that $\mathrm{HCl}$ should not be used for $\mathrm{N}_{2} \mathrm{O}$ production experiments as $\mathrm{N}_{2} \mathrm{O}$ is produced from abiotic $\mathrm{NO}_{2}{ }^{-}$reduction under acidic and anoxic conditions (Zhu-Barker et al., 2015).

Preserved samples should be stored in the dark and likely keep for several months although the maximum storage time has not been thoroughly tested. We recommend analyzing these samples as soon as possible.

\section{Preparation of Internal Isotope Standards for IRMS Analysis}

Internal isotope standards, to determine the atom fraction of ${ }^{15} \mathrm{~N}$ in $\mathrm{NO}_{2}{ }^{-}$or $\mathrm{NO}_{3}{ }^{-}$, are prepared by mixing solutions of non-labeled $\mathrm{NO}_{2}{ }^{-}$or $\mathrm{NO}_{3}{ }^{-}$salts with ${ }^{15} \mathrm{~N}$-labeled $\mathrm{Na}^{15} \mathrm{NO}_{2}$ or $\mathrm{Na}^{15} \mathrm{NO}_{3}$ (>98.5\%, Cambridge isotope Laboratories) as described in Frame et al. (2017). The isotopic composition of $\mathrm{NO}_{2}{ }^{-}$or $\mathrm{NO}_{3}{ }^{-}$is measured by conversion to $\mathrm{N}_{2} \mathrm{O}$ using the denitrifier and azide methods (Sigman et al., 2001; McIlvin and Altabet, 2005; Weigand et al., 2016).

Alternatively, ${ }^{46} \mathrm{~N}_{2} \mathrm{O}$ gas (Cambridge Isotope Laboratories) and natural abundance $\mathrm{N}_{2} \mathrm{O}$ gas can be mixed using a gas tight syringe in different ratios to obtain a range of labeled $\mathrm{N}_{2} \mathrm{O}$ standards for calibration. Standards should be made to span the expected range of ${ }^{15} \mathrm{~N}$ enrichment in the samples. These isotope standards are used to verify and/or correct the linearity 
of the IRMS and can also be used to calibrate $\mathrm{N}_{2} \mathrm{O}$ isotope measurements for the incubation samples.

The accuracy of the internal standards can be assessed by comparing expected (theoretical) with measured values [as in Frame et al. (2017)]. If standard analytical precautions are followed for preparing the dilution series, the deviation from expected vs. measured values should allow correction for any IRMS linearity effects. The precision can be obtained by measuring several replicates for each dilution.

\section{IRMS Analysis}

$\mathrm{N}_{2} \mathrm{O}$ is analyzed for its concentration and isotopic composition (masses 45/44 and 46/44) using an IRMS with a purge trap system adapted for $\mathrm{N}_{2} \mathrm{O}$ measurements (McIlvin and Casciotti, 2010; Ji et al., 2015; Bourbonnais et al., 2017). Briefly, the samples are degassed directly from the bottle (e.g., Ji et al., 2015) or the water is pumped to an online gas extractor where it is completely degassed (McIlvin and Casciotti, 2010) before IRMS analysis. The lower detection limit of most IRMS is typically $1-5 \mathrm{nmol} \mathrm{N}_{2} \mathrm{O}$. It should be noted that a typical IRMS can only analyze samples to a range of about $5 \%{ }^{15} \mathrm{~N}$ while some instruments are capable of analyzing up to $99 \%{ }^{15} \mathrm{~N}$ using equal collector resistors (e.g., see Bergsma et al., 2001). Some IRMS have the capability of switching between equal and non-equal resistors to enable analysis of both natural abundance and enriched samples.

\section{Rate Calculations}

The equations below describe the calculations using calibrated $\delta^{15} \mathrm{~N}_{\text {sample }}$ and $\delta^{18} \mathrm{O}_{\text {sample values [relative to air (AIR) and }}$ Vienna Standard Mean Ocean Water (VSMOW), respectively] to obtain rates of $\mathrm{N}$ cycling processes. See Sharp (2017) for example calculations that convert raw sample $\delta^{15} \mathrm{~N}$ and $\delta^{18} \mathrm{O}$ values that are expressed relative to an internal reference gas to values expressed relative to AIR and VSMOW using international isotopic reference materials.

Incorporation of tracer during ${ }^{15} \mathrm{~N}$ incubations results in an excess of $\mathrm{m} / \mathrm{z} 45$ and $46 \mathrm{~N}_{2} \mathrm{O}$ :

(1) Total ${ }^{45} \mathrm{~N}_{2} \mathrm{O}={ }^{15} \mathrm{~N}^{14} \mathrm{~N}^{16} \mathrm{O}+{ }^{14} \mathrm{~N}^{15} \mathrm{~N}^{16} \mathrm{O}+{ }^{14} \mathrm{~N}^{14} \mathrm{~N}^{17} \mathrm{O}$

(2) Total ${ }^{46} \mathrm{~N}_{2} \mathrm{O}={ }^{15} \mathrm{~N}^{15} \mathrm{~N}^{16} \mathrm{O}+{ }^{14} \mathrm{~N}^{14} \mathrm{~N}^{18} \mathrm{O}$

To determine the quantities of ${ }^{45} \mathrm{~N}_{2} \mathrm{O}$ and ${ }^{46} \mathrm{~N}_{2} \mathrm{O}$ for each sample, the measured 45/44 and 46/44 ratios are first normalized to AIR for $\mathrm{N}$ and VSMOW for $\mathrm{O}$ :

(3) $\delta{ }^{15} \mathrm{~N}_{\text {sample }}=\left({ }^{15} \mathrm{R}_{\text {sample }} /{ }^{15} \mathrm{R}_{\text {air }}-1\right) \times 1000$

(4) $\delta^{18} \mathrm{O}_{\text {sample }}=\left({ }^{18} \mathrm{R}_{\text {sample }} /{ }^{18} \mathrm{R}_{\text {SMOW }}-1\right) \times 1000$

(5) ${ }^{15} \mathrm{R}=\left[{ }^{15} \mathrm{~N}\right] /\left[{ }^{14} \mathrm{~N}\right]$

(6) ${ }^{18} \mathrm{R}=\left[{ }^{18} \mathrm{O}\right] /\left[{ }^{16} \mathrm{O}\right]$

(7) ${ }^{17} \mathrm{R}=\left[{ }^{17} \mathrm{O}\right] /\left[{ }^{16} \mathrm{O}\right]$, and ${ }^{17} \mathrm{R}=\left[\left({ }^{18} \mathrm{R} / 0.0020052\right){ }^{0.516}\right]$ $\times 0.0003799$

where 0.0020052 is the $\mathrm{R}$ value for ${ }^{18} \mathrm{O}$ in VSMOW and 0.0003799 is the mass dependent relationship between ${ }^{17} \mathrm{O}$ and ${ }^{18} \mathrm{O}$ (Sharp, 2017).

Because there are $2 \mathrm{~N}$ atoms in $\mathrm{N}_{2} \mathrm{O}$, these isotopic ratios can then be substituted into:

(8) ${ }^{45} \mathrm{~N}_{2} \mathrm{O} /{ }^{44} \mathrm{~N}_{2} \mathrm{O}=2 \times{ }^{15} \mathrm{R}+{ }^{17} \mathrm{R}$

(9) ${ }^{46} \mathrm{~N}_{2} \mathrm{O} /{ }^{44} \mathrm{~N}_{2} \mathrm{O}=2 \times{ }^{15} \mathrm{R} \times{ }^{17} \mathrm{R}+{ }^{18} \mathrm{R}+{ }^{15} \mathrm{R}^{2}$
${ }^{45} \mathrm{~N}_{2} \mathrm{O}$ and ${ }^{46} \mathrm{~N}_{2} \mathrm{O}$ are finally calculated by converting the calibrated molecular ratios, $\mathrm{R},\left({ }^{45} \mathrm{~N}_{2} \mathrm{O} /{ }^{44} \mathrm{~N}_{2} \mathrm{O}\right.$ and $\left.{ }^{46} \mathrm{~N}_{2} \mathrm{O} /{ }^{44} \mathrm{~N}_{2} \mathrm{O}\right)$ to moles of ${ }^{45} \mathrm{~N}_{2} \mathrm{O}$ and ${ }^{46} \mathrm{~N}_{2} \mathrm{O}$ :

(10) $\left[{ }^{45} \mathrm{~N}_{2} \mathrm{O}\right]=\left[\mathrm{N}_{2} \mathrm{O}\right] \times\left[{ }^{45} \mathrm{~N}_{2} \mathrm{O}\right] /\left[{ }^{44} \mathrm{~N}_{2} \mathrm{O}\right] /\left(1+\left[{ }^{45} \mathrm{~N}_{2} \mathrm{O}\right] /\right.$ $\left.\left[{ }^{44} \mathrm{~N}_{2} \mathrm{O}\right]+\left[{ }^{46} \mathrm{~N}_{2} \mathrm{O}\right] /\left[{ }^{44} \mathrm{~N}_{2} \mathrm{O}\right]\right)$

(11) $\left[{ }^{46} \mathrm{~N}_{2} \mathrm{O}\right]=\left[\mathrm{N}_{2} \mathrm{O}\right] \times\left[{ }^{46} \mathrm{~N}_{2} \mathrm{O}\right] /\left[{ }^{44} \mathrm{~N}_{2} \mathrm{O}\right] /\left(1+\left[{ }^{45} \mathrm{~N}_{2} \mathrm{O}\right] /\right.$ $\left.\left[{ }^{44} \mathrm{~N}_{2} \mathrm{O}\right]+\left[{ }^{46} \mathrm{~N}_{2} \mathrm{O}\right] /\left[{ }^{44} \mathrm{~N}_{2} \mathrm{O}\right]\right)$

Incorporation of tracer ${ }^{15} \mathrm{~N}$ into $\mathrm{N}_{2} \mathrm{O}$ over the course of the incubation produces an excess of mass ${ }^{45} \mathrm{~N}_{2} \mathrm{O}$ and/or ${ }^{46} \mathrm{~N}_{2} \mathrm{O}$ (calculated for each time point with Equations 10,11). $\mathrm{N}_{2} \mathrm{O}$ production can be calculated based on the equations for $\mathrm{N}_{2} \mathrm{O}$ by Trimmer et al. (2016) ( $\mathrm{nmol} \mathrm{N} \mathrm{O} \mathrm{L}^{-1} \mathrm{~d}^{-1}$ ) (Equations 1216 below).

The underlying assumptions for each treatment (Table $\mathbf{1}$ and Figure 2) are:

(1) ${ }^{15} \mathrm{NH}_{4}{ }^{+}$and unlabeled $\mathrm{NO}_{2}{ }^{-}$incubations: $\mathrm{NH}_{4}{ }^{+}$ oxidation (hydroxylamine oxidation) produces ${ }^{46} \mathrm{~N}_{2} \mathrm{O}$ from two labeled $\mathrm{NH}_{4}{ }^{+}$(Equation 12) and some ${ }^{45} \mathrm{~N}_{2} \mathrm{O}$ labeled $\mathrm{N}_{2} \mathrm{O}$ based on a binomial distribution (Equation 13). Production of excess ${ }^{45} \mathrm{~N}_{2} \mathrm{O}$ indicates hybrid $\mathrm{N}_{2} \mathrm{O}$ formation (see Figure 2 and Equation 14).

(2) ${ }^{15} \mathrm{NO}_{2}{ }^{-}$and unlabeled $\mathrm{NH}_{4}{ }^{+}$incubations: Nitrifierdenitrification and denitrification both mainly produce ${ }^{46} \mathrm{~N}_{2} \mathrm{O}$ (Equation 12). Excess ${ }^{45} \mathrm{~N}_{2} \mathrm{O}$ indicates hybrid $\mathrm{N}_{2} \mathrm{O}$ production by archaeal nitrifiers (Equation 15) or fungi (Shoun et al., 2012).

(3) ${ }^{15} \mathrm{NO}_{3}{ }^{-}$incubations: Only denitrification produces ${ }^{46} \mathrm{~N}_{2} \mathrm{O}$ (Equation 12).

(12) Rate $_{\text {exogenous }}=$ slope ${ }^{46} \mathrm{~N}_{2} \mathrm{O} \times(\mathrm{F})^{-2}$

(13) $\mathrm{p}^{45} \mathrm{~N}_{2} \mathrm{O}_{\text {expected }}=$ slope ${ }^{46} \mathrm{~N}_{2} \mathrm{O} \times 2 \times(1-\mathrm{F}) \times(\mathrm{F})^{-1}$

(14) $\mathrm{p}^{45} \mathrm{~N}_{2} \mathrm{O}_{\text {excess }}=$ slope ${ }^{45} \mathrm{~N}_{2} \mathrm{O}-\mathrm{p}^{45} \mathrm{~N}_{2} \mathrm{O}_{\text {expected }}$

(15) Rate $_{\text {hybrid }}=(\mathrm{F})^{-1} \times\left[\right.$ slope $^{45} \mathrm{~N}_{2} \mathrm{O}+2 \times$ slope $^{46} \mathrm{~N}_{2} \mathrm{O}$ $\times(1-\mathrm{F})]$

(16) Rate $_{\text {total }}=$ Rate $_{\text {exogenous }}+$ Rate $_{\text {hybrid }}$

where $\mathrm{F}\left[{ }^{15} \mathrm{~N} /\left({ }^{15} \mathrm{~N}+{ }^{14} \mathrm{~N}\right)\right]$ is the fraction of ${ }^{15} \mathrm{~N}$ in the substrate pool $\left(\mathrm{NH}_{4}{ }^{+}, \mathrm{NO}_{2}{ }^{-}\right.$, or $\left.\mathrm{NO}_{3}{ }^{-}\right)$, which is assumed to be constant over the incubation time. If known, uncertainties in $\mathrm{F}$ should be propagated to uncertainties in the rate calculations (Supplementary Material, Spreadsheet $\mathrm{N}_{2} \mathrm{OPR}$ ). Exogenous refers to the conversion of externally supplied $\mathrm{N}$ to $\mathrm{N}_{2} \mathrm{O}$. Concentrations before and after tracer addition should be measured to determine the exact addition made. The ${ }^{45} \mathrm{~N}_{2} \mathrm{O}$ that is produced estimated from the binomial distribution and the additional ${ }^{45} \mathrm{~N}_{2} \mathrm{O}$ that is produced through a hybrid $\mathrm{N}_{2} \mathrm{O}$ production pathway can be disentangled using the above equations (Trimmer et al., 2016). The reader is referred to the calculation template in the Supplementary Material (Spreadsheet $\mathrm{N}_{2} \mathrm{OPR}$ ) for example calculations. It should be noted that the "total rate of $\mathrm{N}_{2} \mathrm{O}$ production" and "\% hybrid" calculated here refers to the rate of $\mathrm{N}_{2} \mathrm{O}$ production and \% of hybrid from a particular labeled substrate. Care should be taken in interpreting this as hybrid $\%$ of total $\mathrm{N}_{2} \mathrm{O}$ production if there is substantial production of exogenous $\mathrm{N}_{2} \mathrm{O}$ from other substrates, such as $\mathrm{NO}_{3}^{-}$, in parallel incubations. 


\section{Waste Handling}

$\mathrm{HgCl}_{2}$ and $\mathrm{ZnCl}_{2}$ are highly hazardous chemicals and waste should be disposed of accordingly.

\section{Part B: Tracer Incubations for $\mathrm{N}_{2} \mathrm{O}$ Consumption}

Two main methods are used to perform ${ }^{15} \mathrm{~N}-\mathrm{N}_{2} \mathrm{O}$ incubation experiments to measure $\mathrm{N}_{2} \mathrm{O}$ reduction rates during denitrification (Figure 5). These methods are refereed to below as method \#1 (Babbin et al., 2015; Sun et al., 2020) and method \#2 (Holtappels et al., 2011). Unless specified, the steps below apply to both methods.

\section{Supplies for Tracer Incubations for $\mathrm{N}_{2} \mathrm{O}$ Consumption General Supplies (for Both Methods)}

\section{Chemicals/Gases}

- Saturated $\mathrm{KCl}$ solution

- Glass bottles with ${ }^{15} \mathrm{~N}-\mathrm{N}_{2} \mathrm{O}$ tracer (Cambridge Isotope Laboratories Inc., part \#NLM-1046-PK, purity > 98\%)

- Saturated solution of $\mathrm{HgCl}_{2}$ or $50 \%$ (w/v) $\mathrm{ZnCl}_{2}$

- $\mathrm{He}$ and $\mathrm{N}_{2}$ gas tanks for purging (UHP 5.0 to 4.6 grade)

\section{Other Supplies}

- MilliQ water supply

- Disposable gloves

- $12 \mathrm{~mL}$ Labco exetainers (Labco $12 \mathrm{~mL}$ exetainers, flat bottom, labeled, DW cap, \#739W) in tube racks, labeled, with caps removed

- Exetainer caps, deoxygenated in anaerobic chamber or stored under $\mathrm{He}$ atmosphere before the sampling expedition

- Tygon tubing (approximately $1 \mathrm{~m}$ length) with adaptors to fit the Niskin bottle opening

- Luer-lock gas tight glass syringes [2.5 mL (Hamilton \#81420) or $5 \mathrm{~mL}$ (Hamilton \#81501)] and several needles $\left(26 \mathrm{G} \times 3 / 8^{\prime \prime}\right)$ for $\mathrm{KCl}$ injection

- Fixed needle gas tight glass syringes for ${ }^{15} \mathrm{~N}-\mathrm{N}_{2} \mathrm{O}$ addition: e.g., Hamilton, sample lock: $1 \mathrm{~mL}$ (\#81356), $500 \mu \mathrm{L}$ (\#81256), $250 \mu \mathrm{L}$ (\#81156), and $100 \mu \mathrm{L}$ (\#81056) (volume is based on desired ${ }^{15} \mathrm{~N}-\mathrm{N}_{2} \mathrm{O}$ tracer addition) and $26 \mathrm{G} \times 3 / 8^{\prime \prime}$ needles

- Manifold to simultaneously purge 10-15 exetainers $(12 \mathrm{~mL})$. The purging rack should preferably be made using Viton tubing* (e.g., 1/16" ID × 1/8" OD, Fisher Scientific, \#NC0511742) (see Figure 6A)

- 18G, 6" stainless steel needle* (that reaches the bottom of the bottle) for purging the liquid phase (e.g., Cadence science \#9860) or $21 \mathrm{G} \times 43 / 4^{\prime \prime}$ (B Braun \#4665643) (depending on bottle size)

- Shorter outlet needle for pressure balance during purging* [e.g., BD PrecisionGlide Regular Bevel needles, e.g., $\left.25 \mathrm{G} \times 5 / 8^{\prime \prime}(\# 305122)\right]$

- Dual stage regulators, stainless steel or brass tubing and Swagelok fittings, and mechanical flow controller (e.g., Porter, VCD-1000) for purging
- Incubator (or temperature-controlled room or container) covering the in situ temperature range of the samples

- $\mathrm{O}_{2}$ probe/meter and oxygen sensor spots (Oxysense, Pyroscience, or custom-made sensor spots as in Larsen et al., 2016) for $\mathrm{O}_{2}$ monitoring during incubations

- Paper towels

- Colored tape and Sharpies for sample labeling

- Notebook, log sheets and pens

- IRMS adapted for $\mathrm{N}_{2} / \mathrm{Ar}$ measurements (e.g., see Charoenpong et al., 2014) and for $\mathrm{N}_{2} \mathrm{O}$ isotope measurements [see McIlvin and Casciotti (2010)] by either manual injection (Dalsgaard et al., 2012) or using an autosampler

\section{Additional Supplies Required for Method \#1}

- Glove bag (Sigma Aldrich, AtmosBag)

- $320 \mathrm{~mL}$ glass bottles (Wheaton, BOD Bottle, $300 \mathrm{ml}, 227497-00 \mathrm{G}$ )

- Repeat pipettor and adaptor for $50 \mathrm{~mL}$ repeater pipette tips

- A thin tube that can be attached to the pipette tip and is long enough to reach the bottom of the $320 \mathrm{~mL}$ glass bottle

- Anaerobic chamber (GasPak, 150 Large Anaerobic Systems) with catalyst (BD BBL ${ }^{\mathrm{TM}} \mathrm{GasPak}^{\mathrm{TM}}$ anaerobic and $\mathrm{CO}_{2}$ indicators)

- Beaker for excess seawater

\section{Additional Supplies Required for Method \#2}

- Serum borosilicate glass bottles (200 mL; note: total volume is $250 \mathrm{~mL}$ ) with a $20 \mathrm{~mm}$ opening diameter (Ochs \#102041; Kimble \#61000G-200) or

- Serum borosilicate glass bottles $(500 \mathrm{~mL}$, Wheaton \#223952) with a $30 \mathrm{~mm}$ opening, $30 \mathrm{~mm}$ outer diameter (OD) gray bromobutyl septa (Wheaton, \#224100-331), $30 \mathrm{~mm}$ OD aluminum crimp seals (Wheaton, \#224197-01, and $30 \mathrm{~mm}$ seal crimper (Wheaton, \#224357) and decapper (Wheaton, \#224307)

- Gray butyl septa (20 mm) (Wheaton \#20-0025) (these septa need to be deoxygenated in anaerobic chamber or boiled for $5 \mathrm{~min}$ and stored under $\mathrm{He}$ atmosphere before the sampling expedition)

- Aluminum crimp seals (20 mm) (Wheaton \#224178-01)

- Crimper and decrimper for $20 \mathrm{~mm}$ caps

- $1 \mathrm{~mL}$ luer-lock syringe (BD \#309628) connected to a $16 \mathrm{G} \times 1^{\prime \prime}(\mathrm{BD} \# 305197)$ needle, cut-off flange end and plunger removed (see Figure 5, setup \#2)

Note: In Holtappels et al. (2011), a plastic syringe is used to dispense the seawater into the exetainers. To limit the use of plastic components (potential for oxygen contamination), we recommend attaching a stainless steel luer-lock fitting to the outlet needle (16G), which is connected to a short piece of gas tight Viton tubing with a glass tube on the end (long enough to reach the bottom of an exetainer). This approach also makes dispensing the seawater into exetainers easier.

- Various size needles 21G × 43/4" (B Braun \#4665643) and $23 \mathrm{G} \times 1^{\prime \prime}(\mathrm{BD} \# 305145)$

- Luer-lock syringes: BD luer-lock tip 3 ml (\#309657) 


\section{N- N2O incubation experiments}

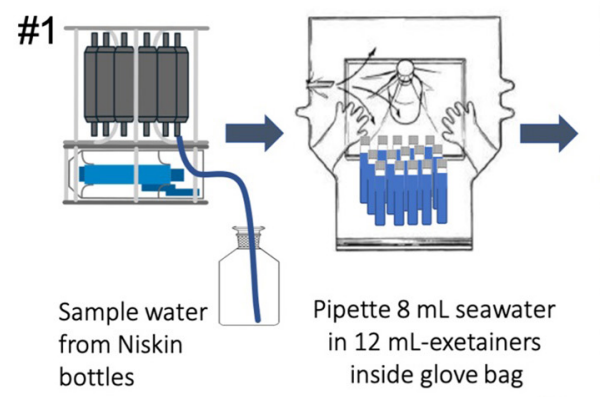

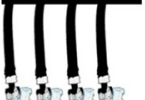

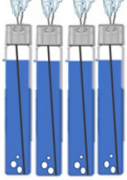

Purge with $\mathrm{He}$ for 5 minutes
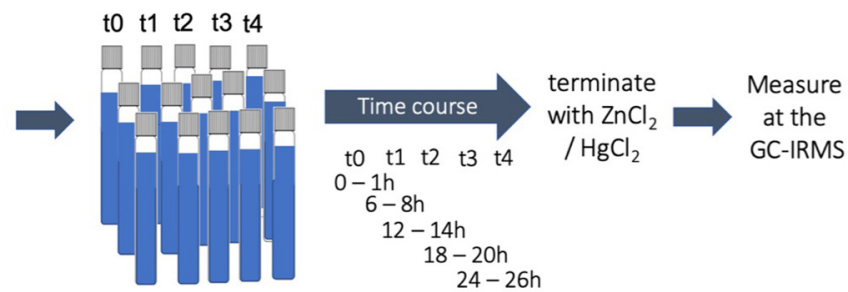

$+{ }^{15} \mathrm{~N}-\mathrm{N}_{2} \mathrm{O}$

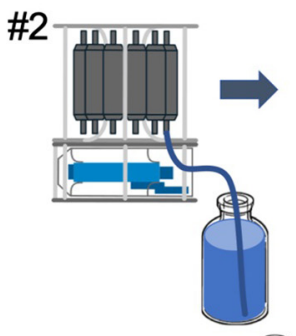

Sample water from Niskin bottles

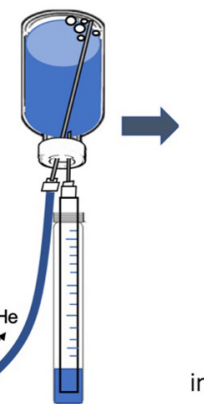

and purge
$2 \times$ with He
for 15 seconds
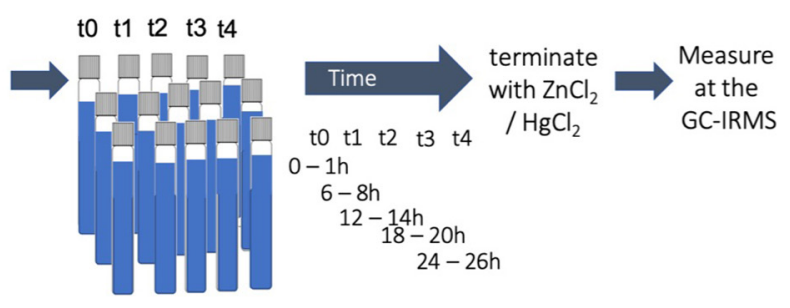

to t1 $6-8 \mathrm{~h}$ $12-14 \mathrm{~h}-20 \mathrm{~h}$ $24-26 h$

FIGURE 5 | Workflow showing ${ }^{15} \mathrm{~N}-\mathrm{N}_{2} \mathrm{O}$ incubation experiments to measure $\mathrm{N}_{2} \mathrm{O}$ reduction rates during denitrification according to Babbin et al. (2015) (method \#1) and according to Holtappels et al. (2011) (method \#2).

A

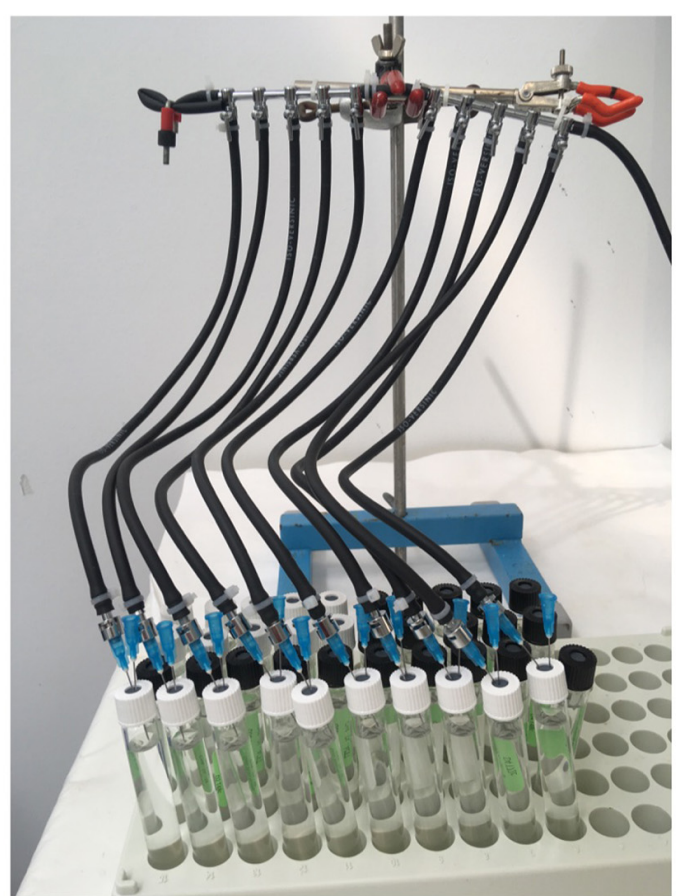

B

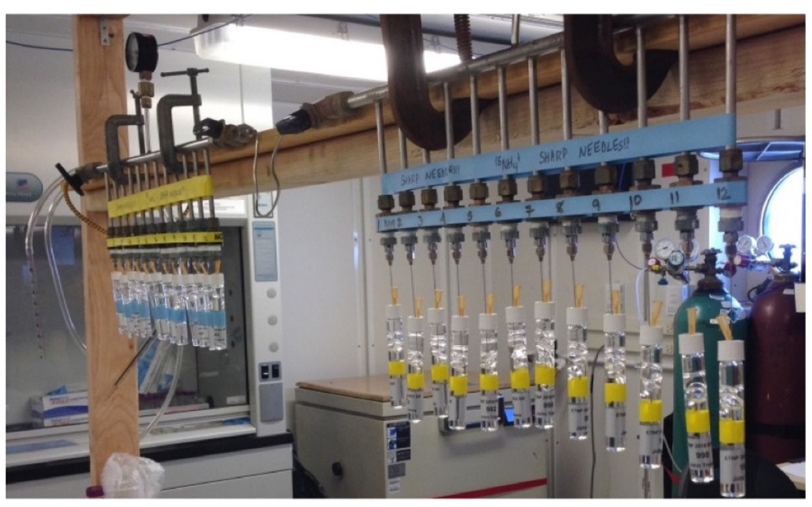

C

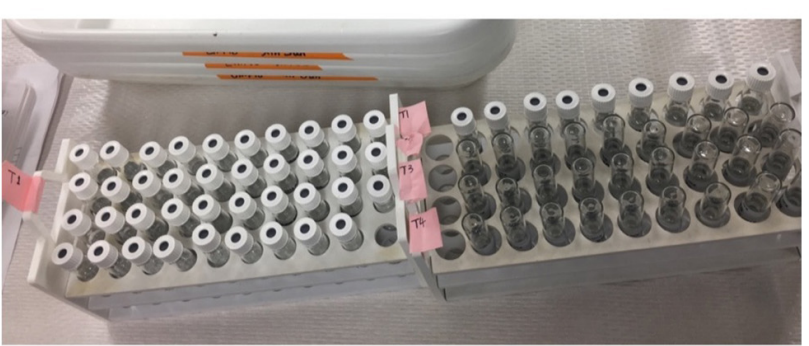

FIGURE 6 | Example purging racks using for method 1 (B), and method 2 (A). In panel (B), $8 \mathrm{~mL}$ seawater in $12 \mathrm{~mL}$ exetainers are purged with He for $5 \mathrm{~min}$ before ${ }^{15} \mathrm{~N}-\mathrm{N}_{2} \mathrm{O}$ tracer addition. Each purging manifold shown here conveniently allows purging the liquid phase of 10 to 12 exetainers at once. $12 \mathrm{~mL}$ exetainers with seawater samples in tube racks organized by time points (C). 


\section{Preparation Before the Sampling Expedition Degas the Caps}

Degas the caps at least 1 month in advance of the sampling expedition (see De Brabandere et al., 2012), and store the empty uncapped, labeled exetainers covered with plastic wrap in their original boxes. Caps are deoxygenated by storing them in plastic Ziploc bags (24 caps/bag) in anaerobic chambers with a catalystic $\mathrm{O}_{2}$ scavenger, and flushed with $\mathrm{He}$ (or evacuated and filled with He several times). Alternatively, stoppers are stored under a He atmosphere in a gas tight bottle (flushed regularly with $\mathrm{He}$ ).

\section{Prepare Exetainers and Caps Before Sampling}

Place the empty exetainers in test tube racks in sets of 12 tubes per treatment per depth (12 vials for standard ${ }^{15} \mathrm{~N}-\mathrm{N}_{2} \mathrm{O}$ treatment: four time points in triplicate or use 15 tubes if five time points are desired).

\section{Prepare ${ }^{15} \mathrm{~N}-\mathrm{N}_{2} \mathrm{O}$ Tracer Before the Sampling Expedition}

Dilute ${ }^{15} \mathrm{~N}-\mathrm{N}_{2} \mathrm{O}$ tracer in $\mathrm{He}$ to obtain the desired tracer concentration. First, at least two $250 \mathrm{~mL}$ glass serum bottles capped with gray butyl stoppers and aluminum seals are purged with $\mathrm{He}$ for $5 \mathrm{~min}$ at 5 PSI pressure $\left(\sim 500 \mathrm{ml} \mathrm{min}^{-1}\right)$ using $22 \mathrm{G}$ needles, to purge the bottle (make sure that there is $\mathrm{He}$ outflow from the serum bottles). Second, add the desired amount of ${ }^{15} \mathrm{~N}-\mathrm{N}_{2} \mathrm{O}$ tracer (e.g., $5 \mathrm{~mL}$ (50 times dilution of $99 \%{ }^{15} \mathrm{~N}$ $\mathrm{N}_{2} \mathrm{O}$ tracer gas, Cambridge Isotope Laboratories, purity $\geq 98 \%$ ) with a gas tight syringe to one serum bottle that will be used as the stock bottle. Third, based on the desired final ${ }^{15} \mathrm{~N}$ $\mathrm{N}_{2} \mathrm{O}$ tracer concentrations, use a fixed needle gas tight glass syringe to transfer ${ }^{15} \mathrm{~N}-\mathrm{N}_{2} \mathrm{O}$ and $\mathrm{He}$ gas mixture from the stock bottle to He-purged small serum bottles/vials to make several working tracer bottles (depending on the number of samples that will be collected, e.g., use one working tracer bottle per station). We recommend preparing the tracer bottles as close as possible to the sampling expedition date to minimize any leaking or contamination. Tracer concentration should be decided based on (1) the expected final concentration of the tracer in incubation exetainers, which should be within the range of $\mathrm{N}_{2} \mathrm{O}$ concentrations at the sampling site, and (2) the volume of the tracer injected into each exetainer, which should be around $50 \mu \mathrm{L}$. Larger injection volumes will cause positive pressure in exetainers, and smaller injection volumes might introduce volume measurement errors.

To make sure that the tracer stock concentration is the same as the desired concentration, the tracer concentration should be measured prior to the sampling expedition. If the tracer concentration is too high for the Faraday cups of the IRMS, the tracer stock should be subsampled and diluted in He to the level that will not saturate the Faraday cups of the IRMS (typically 5\% $\left.{ }^{15} \mathrm{~N}\right)$. Determine the concentration of the ${ }^{15} \mathrm{~N}-\mathrm{N}_{2} \mathrm{O}$ tracer based on the peak area measured by IRMS and any dilution before the sampling expedition.

\section{Sampling: Method \#1 Only}

Before sampling, place everything you need EXCEPT the $320 \mathrm{~mL}$ bottles in the glove bag. Do not flush the bag yet, and keep bag compressed. Put one bag of caps from the anaerobic chamber with sufficient numbers of caps for the designed experiment inside the glove bag just before CTD-Rosette is back on deck.

\section{Items to Go Into the Glove Bag:}

- Water samples in $320 \mathrm{~mL}$ bottles

- $50 \mathrm{~mL}$ pipette (or repeat pipettor) and tips

Note: If you are also performing denitrification and anammox experiments using the same method, make sure to label pipette and tips distinctly using color coding; e.g., one color for each tracer or carrier addition.

- A thin tube that can be attached to the pipette tips and is long enough to reach the bottom of the $320 \mathrm{~mL}$ glass bottle

- Exetainers in tube racks, labeled, with caps removed

- Exetainer caps from the anaerobic chamber

- Gloves

- Paper towels or sponge to handle spills

- Beaker for excess seawater

These shipboard operations are best done as a three-person team. One person performing the glove bag manipulations, another performing the He flushing and noting the times of tracer addition and purging the liquid phase and the third injecting the ${ }^{15} \mathrm{~N}-\mathrm{N}_{2} \mathrm{O}$ tracer into each exetainer. The task of tracer injection can be shared between the first two persons if only two-person team is available.

\section{For Each Depth Fill 320 mL Round Glass Stoppered Bottles}

Label distinctly the $320 \mathrm{~mL}$ bottles (e.g., using a color code) if you are performing denitrification and anammox experiments using the same method.

Obtain sample water by filling each $320 \mathrm{~mL}$ glass bottle from Niskin bottles using a Tygon tube, which is inserted all the way to the bottom of the bottle, overflow three times the bottle volume, and seal with a glass stopper (ensure no bubbles are present).

Put the bottles with seawater samples into a glove bag. Store bottles if the incubation experiment cannot be performed immediately due to other sampling tasks. Store bottles under conditions similar to in situ (for example $\sim 10^{\circ} \mathrm{C}$ dark room if sampling from dark cold depths), it is recommended that experimental setup starts as soon as possible.

Note station location, date, cast number, depth, incubation condition, and treatment $\left({ }^{15} \mathrm{~N}-\mathrm{N}_{2} \mathrm{O}\right.$ in this case $)$ in notebook.

\section{Aliquot Seawater Into Exetainers Inside a Glove Bag}

Place all $320 \mathrm{~mL}$ sample bottles in the prepared glove bag, compress to remove all air (or evacuate), then fill and evacuate the glove bag three times with $\mathrm{N}_{2}$ by pressing out the gas inside and refilling. Use the $\mathrm{N}_{2}$ tube coming into the glove bag and flush every single open exetainer with gas before opening the $320 \mathrm{~mL}$ glass bottles.

Use the repeat pipettor and $50 \mathrm{~mL}$ pipette tips with the thin tube attached to aliquot $8 \mathrm{~mL}$ of seawater to appropriately labeled exetainers (15 exetainers for each treatment per depth: five time points in triplicates).

Seal vials with deoxygenated exetainer caps. When all exetainers are filled and capped, remove from glove bag for helium sparging. 


\section{Sampling: Method \#2 Only}

Label distinctly the 250 or $500 \mathrm{~mL}$ bottles (e.g., using a color code) if you are performing denitrification and anammox experiments using the same method. The size of bottle used depends on number of replicates and time points.

Fill each 250 or $500 \mathrm{~mL}$ serum bottles from Niskin bottles using a Tygon tube, which is inserted all the way to the bottom of the bottle, and overflow three times the bottle volume. Cap, bubble-free, with a deoxygenated gray butyl stopper and aluminum seal.

Store bottles under conditions similar to in situ (for example $\sim 10^{\circ} \mathrm{C}$ dark room if sampling from dark cold depths) if the incubation experiment cannot be performed immediately due to other sampling tasks. It is recommended that experimental setup starts as soon as possible. Note station location, date, cast number, depth, incubation condition, and treatment $\left({ }^{15} \mathrm{~N}-\mathrm{N}_{2} \mathrm{O}\right.$ in this case) in notebook.

Initially purge with $\mathrm{He}(0.4 \mathrm{~L} / \mathrm{min})$ for at least $15 \mathrm{~min}$ to lower the background concentration of $\mathrm{N}_{2}$ and remove any $\mathrm{O}_{2}$ contamination introduced during sampling. The inflow needle should reach to the bottom of the serum bottle $(21 \mathrm{G})$, while the vent needle (16G, large bore size needed for dispensing) only needs to reach into the top of the bottle, approximately $1 \mathrm{~cm}$ (the helium flow will push out some sample creating a small headspace in the bottle). The vent needle is connected to a $1 \mathrm{~mL}$ syringe with a cut-off flange end (plunger removed). To purge several serum bottles at once, use gas tight tubing with several glass (or Swagelok) $t$-pieces in series to split the helium flow.

Transfer seawater in to $12 \mathrm{~mL}$ exetainers using the $1 \mathrm{~mL}$ syringe with a cut-off flange end (Figure 5, setup \#2). Insert a cut-off flange end syringe to the bottom of the exetainer while He gas is still flowing (the flow should be reduced to control the flow rate during dispensing to approximately $0.15 \mathrm{~L} / \mathrm{min}$ ) into the $250 \mathrm{~mL}$ serum glass bottle. Allow water to overflow at least two times the exetainer volume and close the exetainer (bubble free) with a deoxygenated cap. Repeat (e.g., use 15 tubes if five time points are desired).

\section{Purge Exetainers With $\mathrm{He}$}

Method \#1: (See purging manifold, Figure 6B). Turn on the manifold gas flow and bubble exetainers for $5 \mathrm{~min}$ at 5 PSI (flow rate $=0.5$ to $1 \mathrm{~L} / \mathrm{min}$ ) with $\mathrm{He}$.

(i) Pierce the butyl septa with $23 \mathrm{G} \times 1^{\prime \prime}$ needle (vent needle). Needle only needs to pierce through to the headspace, not be pushed in entirely.

(ii) Attach the vial to a $4^{\prime \prime}$ cannula needle (He inflow), and push on entirely to bottom of vial.

-There should be a steady stream of bubbles in the exetainers.

(iii) After $5 \mathrm{~min}$, increase the pressure to $\sim 5$ PSI and pull vials off the manifold, being sure to remove the exit needle first to create positive pressure to prevent air contamination into the vial.

Method \#2: If using method \#2, a $2 \mathrm{~mL} \mathrm{He}$ headspace is created. We recommend inserting a headspace as any trace amounts of $\mathrm{O}_{2}$ introduced during dispensing will concentrate in the headspace (De Brabandere et al., 2012).

(i) To create a headspace, remove $2 \mathrm{ml}$ of water through the septa using a $3 \mathrm{ml}$ luer-lock syringe and needle $\left(23 \mathrm{G} \times \mathrm{1}^{\prime \prime}\right)$, while adding helium simultaneously through a second needle $\left(23 G \times 1^{\prime \prime}\right)$. The exetainers should be vigorously shaken after inserting the headspace.

(ii) The headspace of the exetainers is then flushed with $\mathrm{He}$ twice for $15 \mathrm{~s}$ (approximately $0.5 \mathrm{~L} / \mathrm{min}$, using $23 \mathrm{G} \times 1^{\prime \prime}$ as inflow and vent needles), shaking vigorously in between (De Brabandere et al., 2012). Manifolds can be purchased (e.g., Ochs \# 192012) or produced in house, preferably in metal or glass allowing multiple exetainers to be flushed at once.

Although not always possible, it is preferable to do all these manipulations under in situ conditions, i.e., in situ temperature, and under red light (if the samples were collected from below the euphotic zone).

\section{Tracer Addition}

Add $\sim 50 \mu \mathrm{L}$ of ${ }^{15} \mathrm{~N}-\mathrm{N}_{2} \mathrm{O}$ tracer into the liquid phase in each exetainer to visually confirm that the gas is injected, and the needle is not clogged. Note time of tracer injection, shake gently and invert vials to start the incubation at in situ temperature and light level.

In the tracer bottle, replace the tracer taken out with the same volume of saturated $\mathrm{KCl}$ solution (purged with $\mathrm{He}$ ) to balance the pressure using a luer-lock syringe connected to a needle.

Other gases $\left(\mathrm{H}_{2} \mathrm{~S}, \mathrm{CH}_{4}, \mathrm{CO}_{2}\right)$ lost during the He purge step can also be added back (either as a gas or dissolved) to reproduce as closely as possible in situ conditions before incubating.

\section{Incubation}

Replicate (preferably triplicate) samples per time point amended with ${ }^{15} \mathrm{~N}$ tracer as well as replicate $t=0$ controls immediately killed after ${ }^{15} \mathrm{~N}$-tracer addition should be incubated at in situ temperature and light level using at least three time points for up to a 48 -h period.

Ideally, the concentration of $\mathrm{O}_{2}$ in the exetainer is monitored over time during the incubation using non-invasive $\mathrm{O}_{2}$ measurement technology, such as Oxysense (see text footnote 1) or Pyroscience (see text footnote 2). A sensor dot is attached to the bottom of a subset of exetainers prior to sampling. After injecting the tracer, the $\mathrm{O}_{2}$ concentration is measured continuously or at discrete time points using a fiber optic pen to ensure low- $\mathrm{O}_{2}$ conditions are maintained during the incubations.

\section{Termination}

Add $50 \mu \mathrm{L}$ of a five times diluted saturated solution of $\mathrm{HgCl}_{2}$ or $50 \%$ (w/v) $\mathrm{ZnCl}_{2}$ to each vial with a $1 \mathrm{~mL}$ plastic syringe to arrest microbial activity. Diluting the $\mathrm{HgCl}_{2}$ saturated solution reduces the toxicity of the hazardous wastes without any impact on sample preservation (e.g., see Bourbonnais et al., 2017; Casciotti et al., 2018). Shake the vial for 3 s to mix in the fixative. The replicate control exetainers $\left(T_{0}\right)$ immediately sacrificed after adding the tracer for each treatment are used 
to quantify abiotic $\mathrm{N}_{2}$ production, if any, due to preservative addition and during storage. Note the time when the $T_{0}, T_{1}$, $\mathrm{T}_{2}, \mathrm{~T}_{3}$, exetainers are sacrificed. Preserve at other time intervals, adjusting times depending on the activity expected for the sampled environment (shorter time intervals are preferable in higher activity settings): $T_{1}=7-9 \mathrm{~h}, T_{2}=15-17 \mathrm{~h}$, and $T_{3}=23-$ $25 \mathrm{~h}$.

Preserved $\mathrm{N}_{2}$ samples can be stored in the dark and likely keep for several months but measuring samples at soon as possible is highly recommended. Place the vials upside down in the darkto reduce diffusion across septa. Precipitates caused by $\mathrm{ZnCl}_{2}$ acts as barrier.

\section{IRMS Analysis}

Before analyzing samples on the IRMS in the home laboratory, place the samples on a reciprocal shaker $(\sim 150 \mathrm{rpm})$ overnight to equilibrate the $\mathrm{N}_{2}$ with the headspace. Shaking also facilitates removal of insoluble salts from the septum that can clog the autosampler needle. When analyzing samples from ${ }^{15} \mathrm{~N}-\mathrm{N}_{2} \mathrm{O}$ incubations, a liquid $\mathrm{N}_{2}$ cryotrap should be used to remove ${ }^{15} \mathrm{~N}$ $\mathrm{N}_{2} \mathrm{O}$ to minimize interference from conversion to ${ }^{30} \mathrm{~N}_{2}$ by the copper column (Dalsgaard et al., 2012).

$\mathrm{N}_{2}$ standards should be prepared in exetainers on the day of measurement. Standard exetainers should be prepared in the same way as sample exetainers: 8 (or 10) $\mathrm{mL}$ of $\mathrm{NaCl}$ solution with salinity adjusted to match that of the sample water should be added into each exetainer. Purge the standard exetainers with He for $5 \mathrm{~min}$, and then inject different volumes of unlabeled $\mathrm{N}_{2}$. The different amounts of $\mathrm{N}_{2}$ injected should bracket the amount of $\mathrm{N}_{2}$ in sample exetainers. Standards will be used to calculate the amount of $\mathrm{N}_{2}$ in each sample exetainer. If possible, standards with different ratios of ${ }^{30} \mathrm{~N}_{2}$ to ${ }^{28} \mathrm{~N}_{2}$ should be used to cover the range of $\mathrm{m} / \mathrm{z} 30$ signals in the samples and test the accuracy of the measured ${ }^{30} \mathrm{~N}_{2} /{ }^{28} \mathrm{~N}_{2}$.

The isotopic composition and amount of $\mathrm{N}_{2}$ are determined using a continuous flow system interfaced to the IRMS [Bulow et al., 2010; Babbin et al., 2015; also see Charoenpong et al. (2014) for more information regarding the IRMS set up for these analyses] or a membrane inlet coupled to a quadrupole mass spectrometer (Kana et al., 1994). In all cases, $\mathrm{O}_{2}$ must be removed from the samples using a furnace containing a $\mathrm{Cu}$ flow path as the presence of $\mathrm{O}_{2}$ has been shown to cause isobaric interferences in the mass spectrometer source by reaction with $\mathrm{N}_{2}$ to create $\mathrm{NO}_{x}$ (Bender et al., 1994; Emerson et al., 1999).

If necessary, a non-labeled (i.e., at natural abundance) $\mathrm{N}_{2}$ carrier gas might be added back into the exetainers before analysis to (1) lower the ${ }^{15} \mathrm{~N}$ enrichment to be within the range that can be measured by the mass spectrometer and (2) to assure sufficient quantities of $\mathrm{N}_{2}$ for analysis on the IRMS.

\section{Rate Calculations}

$\mathrm{N}_{2} \mathrm{O}$ consumption rates from denitrification are calculated from the excess of ${ }^{30} \mathrm{~N}_{2}$ produced during ${ }^{15} \mathrm{~N}-\mathrm{N}_{2} \mathrm{O}$ tracer incubations according to Babbin et al. (2015). Assuming any preexisting unlabeled $\mathrm{N}_{2} \mathrm{O}$ was removed during the experimental setup (purging steps), the fraction label is $100 \%$, thus:
(17) Rate $_{\text {consumption }}=$ slope $^{30} \mathrm{~N}_{2}$, i.e., ${ }^{30} \mathrm{~N}_{2}\left(\mathrm{nM}-\mathrm{N}_{2}\right)$ changing over time (hour or day).

The concentration of ${ }^{30} \mathrm{~N}_{2}$ in each sample exetainer is calculated based on the area of ${ }^{30} \mathrm{~N}_{2}$ relative to the areas for standard exetainers measured during IRMS analysis.

The reader is referred to the calculation template in the Supplementary Material (Spreadsheet $\mathrm{N}_{2} \mathrm{OCON}$ ) for a better understanding and traceability of the given equations.

\section{Waste Handling}

$\mathrm{HgCl}_{2}$ or $\mathrm{ZnCl}_{2}$ are highly hazardous wastes and should be disposed of accordingly.

\section{RESULTS}

Figure 7 and Supplementary Material (Spreadsheet $\mathrm{N}_{2} \mathrm{OPR}$ ) show an example of the increase in masses ${ }^{44} \mathrm{~N}_{2} \mathrm{O},{ }^{45} \mathrm{~N}_{2} \mathrm{O}$, and ${ }^{46} \mathrm{~N}_{2} \mathrm{O}$ over the incubation period following the addition of ${ }^{15} \mathrm{~N}$ $\mathrm{NH}_{4}{ }^{+},{ }^{15} \mathrm{~N}-\mathrm{NO}_{2}{ }^{-}$, and ${ }^{15} \mathrm{~N}-\mathrm{NO}_{3}{ }^{-}$. In all treatments, masses 45 and 46 increase significantly with time, whereas the increase in ${ }^{44} \mathrm{~N}_{2} \mathrm{O}$ is not always significant and depends on the overall rate. The steepness of the slope of the linear regression represents the production rate over time. The enrichment in ${ }^{45} \mathrm{~N}_{2} \mathrm{O}$ or ${ }^{46} \mathrm{~N}_{2} \mathrm{O}$ is also dependent on the fraction of labeled substrate which needs to be taken into account when calculating the overall production rates from a single tracer.

In incubations with relatively small rates $\left(\mathrm{N}_{2} \mathrm{O}\right.$ from $\left.\mathrm{NH}_{4}{ }^{+}=0.047 \pm 0.007 \mathrm{nM}-\mathrm{N}_{2} \mathrm{O} / \mathrm{d}\right)$ mass ${ }^{44} \mathrm{~N}_{2} \mathrm{O}$ is not changing significantly, while in treatments with higher rates mass 44 also increases with time [e.g., $\mathrm{N}_{2} \mathrm{O}$ from $\mathrm{NO}_{3}{ }^{-}=2.56 \pm 0.44 \mathrm{nM} / \mathrm{d}$, see calculation spreadsheet $\mathrm{N}_{2} \mathrm{OPR}$ (Supplementary Material) for $\mathrm{N}_{2} \mathrm{O}$ production rates]. A non-paired two-tailed $t$-test is performed in order to see if the slope over time is significantly different from zero. If the $t$-test $p$ value is higher than 0.05 (for a significance level of 95\%), the production rate is not significant. An increase in the number of replicates or time points reduces the uncertainty of such measurements and decreases the standard error for the linear regression.

It is possible that the product pools change exponentially over time and deviate from linearity, as indicated by a low R-squared for the linear regression. In longer incubations, a curvature generally indicates an artifact due to "bottle effects," where bottle size (surface to volume ratio) or change in $\mathrm{O}_{2}$ concentration artificially stimulate bacterial growth (Garcia-Robledo et al., 2016). We recommend only using the linear portion of the curve for rate calculation and report the most conservative rate.

$\mathrm{N}_{2} \mathrm{O}$ consumption rates are similarly calculated (Figure 8). An example from Sun et al. (2020) is given in Spreadsheet $\mathrm{N}_{2} \mathrm{OCON}$ (Supplementary Material).

\section{DISCUSSION}

We discuss below important considerations and recommendations for $\mathrm{N}_{2} \mathrm{O}$ rate measurements using ${ }^{15} \mathrm{~N}$-tracer incubations, including data reporting and archiving. 

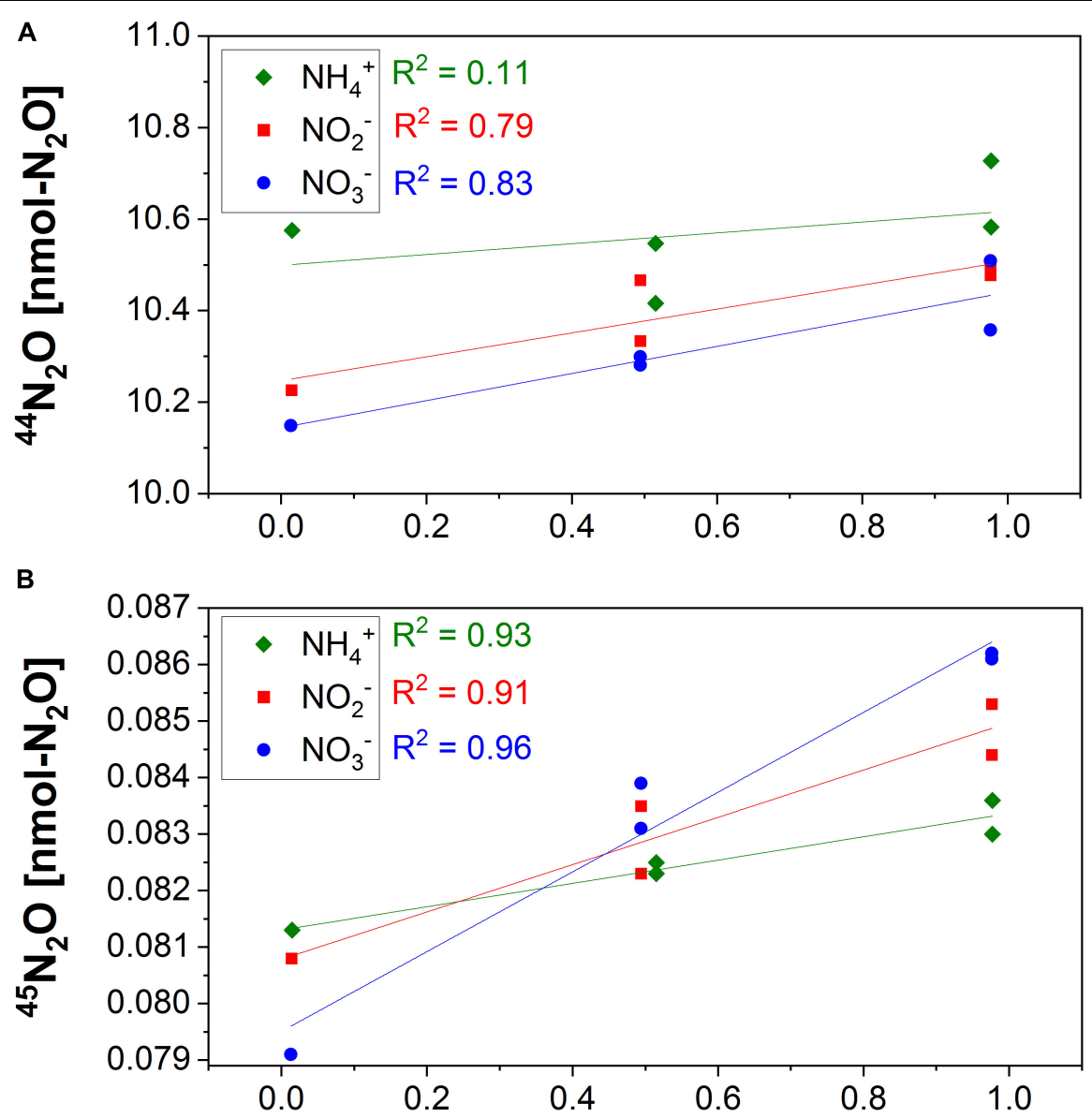

C

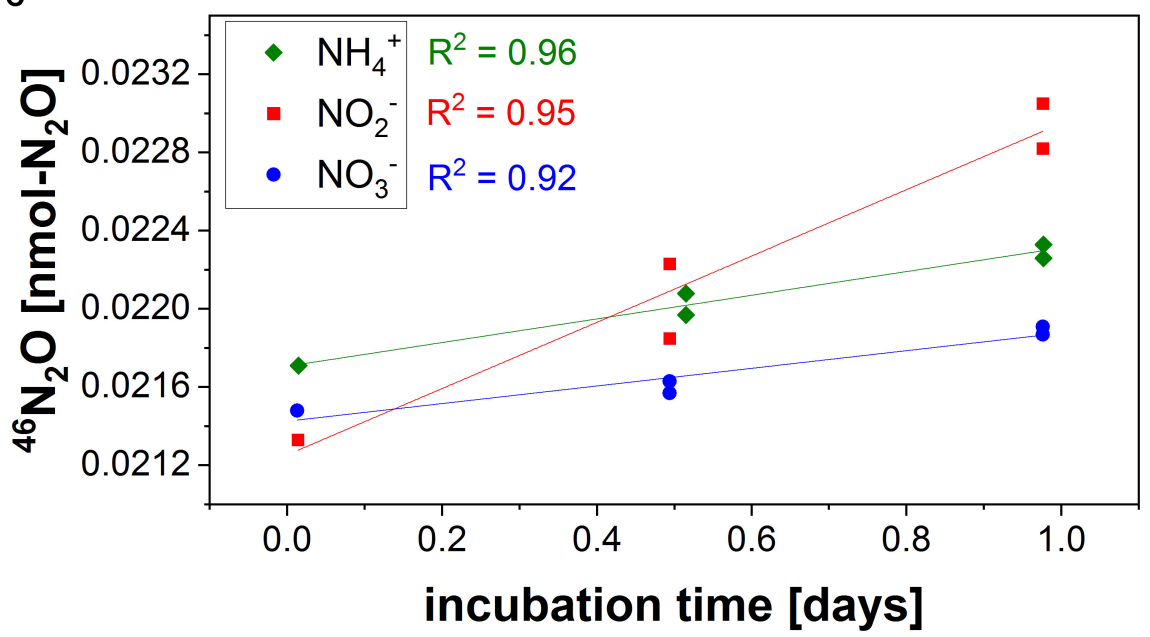

FIGURE 7| ${ }^{44} \mathrm{~N}_{2} \mathrm{O}$ (A), ${ }^{45} \mathrm{~N}_{2} \mathrm{O}$ (B), and ${ }^{46} \mathrm{~N}_{2} \mathrm{O}$ (C) masses over time for $\mathrm{N}_{2} \mathrm{O}$ production ${ }^{15} \mathrm{~N}$-labeled incubations performed in the ETSP on R/N Meteor in June 2017 (Frey et al., 2020). The samples were taken at $220 \mathrm{~m}$ depth above the oxic-anoxic interface off the coast of Peru (sample S4, station 882).

\section{Maintaining Anoxic Conditions Prior and During Incubations}

Precautions are necessary during ${ }^{15} \mathrm{~N}$ incubations of anoxic waters to determine $\mathrm{N}_{2} \mathrm{O}$ production or consumption to $\mathrm{N}_{2}$. One area of concern is $\mathrm{O}_{2}$ contamination from air during sampling from Niskin bottles, which has been reported to result in an increase in dissolved $\mathrm{O}_{2}$ of as much as $1 \mu \mathrm{M}$ (De Brabandere et al., 2012). If possible, it is preferable to replace 


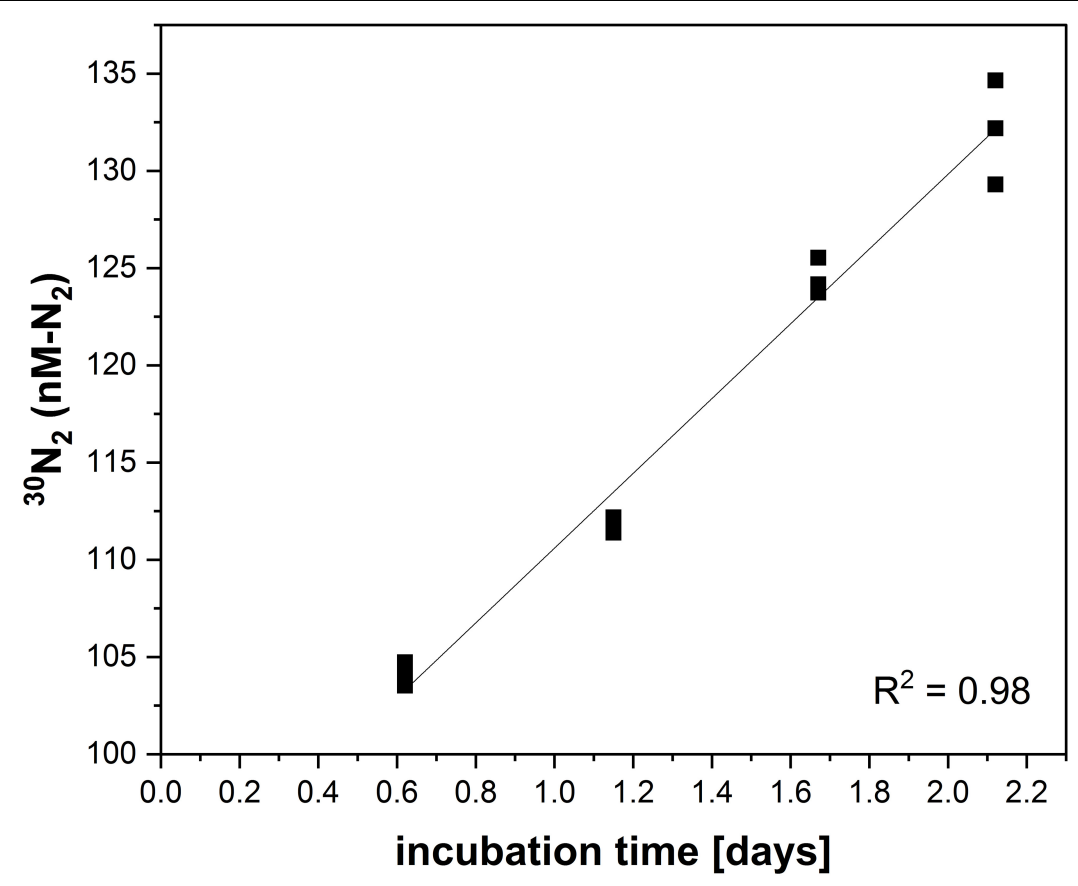

FIGURE 8 | Production of ${ }^{30} \mathrm{~N}_{2}\left(\mathrm{nM}-\mathrm{N}_{2}\right)$ over time for $\mathrm{N}_{2} \mathrm{O}$ consumption ${ }^{15} \mathrm{~N}$-labeled incubations performed in the ETNP on RN Sally Ride in March and April 2018 (Sun et al., 2020). The samples were taken above the oxycline at $60 \mathrm{~m}$ depth (station 2, cast 34).

the headspace created in the Niskin bottle with $\mathrm{CO}_{2}$ or $\mathrm{N}_{2}$ while water is removed rather than simply allowing air invasion. It is also recommended to avoid plastic and rubber components wherever possible as $\mathrm{O}_{2}$ can diffuse through or from these materials (e.g., De Brabandere et al., 2012) and stoppers should be deoxygenated and kept in an anaerobic chamber or under $\mathrm{He}$ atmosphere prior to incubations (see section "Stoppers").

Water collection systems differ in their degree of oxygen contamination. Pump profiling system (PPS) allow sampling directly from the water column which minimizes $\mathrm{O}_{2}$ contamination during sample collection (e.g., Padilla et al., 2016). Sampling from Niskin bottles introduce oxygen contamination in the sample (De Brabandere et al., 2012), thus most research groups typically purge with $\mathrm{He}$ to remove $\mathrm{O}_{2}$ in incubation bottles (e.g., Holtappels et al., 2011; Kalvelage et al., 2013; Frey et al., 2020; Sun et al., 2020). Purging the liquid phase with He before the incubations alters ambient conditions and removes gases such as $\mathrm{N}_{2} \mathrm{O}, \mathrm{CH}_{4}$, and $\mathrm{H}_{2} \mathrm{~S}$ that are intricately linked to the $\mathrm{N}$-cycle. Therefore, potential rates are obtained as is usually the case for these type of incubations due to changes in experimental conditions. If desired, these substrates should be added back after purging. Creating a headspace can also help draw dissolved $\mathrm{O}_{2}$ into the headspace while the more soluble $\mathrm{N}_{2} \mathrm{O}$ remains dissolved in the water sample. The non-invasive monitoring of $\mathrm{O}_{2}$ concentrations inside the incubation bottle is strongly advised (see section "Incubation").

\section{Bottle Types}

A range of bottle types and sizes have been used for ${ }^{15} \mathrm{~N}$ denitrification incubations including, for instance, 1 or $0.5 \mathrm{~L}$ amber glass bottles with Teflon stoppers containing two lengths of $1 / 8^{\prime \prime}$ tygon tubing with valves (Devol et al., 2006; Bourbonnais et al., 2012), $500 \mathrm{~mL}$ bags (Ward et al., 2009; Bourbonnais et al., 2012), or $12 \mathrm{~mL}$ exetainers (Holtappels et al., 2011; Bourbonnais et al., 2012). Tedlar ${ }^{\circledR}$ bags are typically hard to fill without bubble formation and the valves are not usually completely leak-tight. Thus, incubating in bags is discouraged. Larger serum bottles (at least $60 \mathrm{~mL}$ ) with butyl rubber stoppers are recommended to measure $\mathrm{N}_{2} \mathrm{O}$ production rates as $\mathrm{N}_{2} \mathrm{O}$ produced in small volume exetainers might not be sufficient to be detected with the IRMS if rates are low.

\section{Stoppers}

Niemann et al. (2015) found that the thick black, nonhalogenated butyl rubber stoppers leached high amounts of various organic compounds that have toxic effects during aerobic methane oxidation incubations. The gray bromo- and chlorobutyl stopper types tested did not seem to leach any organics. We thus recommend using these types of stoppers, but further tests investigating potential toxic effects of these stoppers during $\mathrm{N}_{2} \mathrm{O}$ production and consumption ${ }^{15} \mathrm{~N}$-labeled incubations are required. Prior to anoxic or low $\mathrm{O}_{2}$ incubations, exetainer caps should be stored under a $\mathrm{He}$ atmosphere to remove $\mathrm{O}_{2}$. Gray butyl rubber stoppers for serum glass bottles should be boiled for about $5 \mathrm{~min}$ in purified (e.g., Milli-Q) water and stored under He atmosphere to remove $\mathrm{O}_{2}$ (De Brabandere et al., 2012).

\section{${ }^{15} \mathrm{~N}$-Tracer Addition}

Ideally, the final concentration of tracer added should be as close as possible to ambient concentrations. However, this is difficult 
to achieve for oxic water-column samples where dissolved $\mathrm{NH}_{4}{ }^{+}$and $\mathrm{NO}_{2}{ }^{-}$typically do not significantly accumulate. For denitrification incubations, additions of at least $5-20 \mu \mathrm{M}$ of ${ }^{15} \mathrm{~N}-\mathrm{NO}_{2}{ }^{-}$or ${ }^{15} \mathrm{~N}-\mathrm{NO}_{3}{ }^{-}$tracers have been used [e.g., Devol et al. (2006); Bourbonnais et al. (2012)] in order to detect production of labeled $\mathrm{N}_{2} \mathrm{O}$ or $\mathrm{N}_{2}$ products when rates are low. Consequently, tracers are commonly added at concentrations of $10-100 \%$ of ambient concentrations, hence potential rates are investigated. The final tracer concentration is typically $0.5-$ $5 \mu \mathrm{M}^{15} \mathrm{~N}-\mathrm{NH}_{4}{ }^{+}$or ${ }^{15} \mathrm{~N}-\mathrm{NO}_{2}{ }^{-}$for water-column samples from oligotrophic waters (see Ji et al., 2015; Frame et al., 2017).

\section{Choosing a Fixative}

While a comprehensive comparison of different fixatives is still lacking, the use of $\mathrm{HgCl}_{2}$ is advised. Ostrom et al. (2016) showed that $\mathrm{ZnCl}_{2}$ or $\mathrm{HgCl}_{2}$ acts as catalyst for abiotic $\mathrm{N}_{2} \mathrm{O}$ production from $\mathrm{Fe}^{2+}$ oxidation coupled to $\mathrm{NO}_{2}{ }^{-}$reduction in anoxic environments where $\mathrm{Fe}^{2+}$ concentrations are relatively high (Antarctica Lake, sediment pore-waters). This should not be a concern for water-column samples because $\mathrm{Fe}^{2+}$ and $\mathrm{NO}_{2}{ }^{-}$ concentrations are generally too low for this abiotic process to be significant. However, at the same time, there is an increasing awareness of how anthropogenic activities impact the mercury cycle and efforts are being made to reduce these emissions. In 2017, during the Minamata convention, Europe agreed to reduce the usage of $\mathrm{Hg}$, including $\mathrm{HgCl}_{2}$. Since then, Sweden has banned $\mathrm{HgCl}_{2}$ from research vessels and other European countries are following. There is an urgent need to find good alternatives.

\section{Data Reporting and Archiving}

We recommend submitting all relevant metadata and data to an open-source public data repository such as Pangaea ${ }^{3}$, the Biological and Chemical Oceanography Data Management Office $\left(\mathrm{BCO}-\mathrm{DMO}^{4}\right)$ or the Pan-European Infrastructure for Ocean and Marine Data Management (SeaDataNet $\left.{ }^{5}\right)$. Metadata should include sampling date, station and GPS site location, depth (m), ${ }^{15} \mathrm{~N}$ treatment, amount of ${ }^{15} \mathrm{~N}$ tracer added, bottle and headspace volume (if applicable), whether the sample was purged or not and gas used for purging the liquid phase, incubation time points, preservative used as well as in situ temperature, oxygen and nutrient $\left(\mathrm{NO}_{3}{ }^{-}, \mathrm{NO}_{2}{ }^{-}\right.$, and $\left.\mathrm{NH}_{4}{ }^{+}\right)$concentrations. $\delta^{15} \mathrm{~N}$ (vs. air) and $\delta^{18} \mathrm{O}$ (vs. VSMOW) as well as calculated quantities of $\left[{ }^{44} \mathrm{~N}_{2} \mathrm{O}\right],\left[{ }^{45} \mathrm{~N}_{2} \mathrm{O}\right.$ ], and $\left[{ }^{46} \mathrm{~N}_{2} \mathrm{O}\right.$ ] (in nmol $\mathrm{N}_{2} \mathrm{O}$ $\mathrm{L}^{-1}$ or nmol $\mathrm{N} \mathrm{L}^{-1}$ ) (see section "Rate Calculations") should also be reported for each time point. $\mathrm{N}_{2} \mathrm{O}$ production and consumption rates can be reported in nmol- $\mathrm{N}_{2} \mathrm{O}$ (or N) $\mathrm{L}^{-1}$ $\mathrm{d}^{-1}$ or nmol $\mathrm{N}_{2} \mathrm{O}$ ( or $\mathrm{N}$ ) $\mathrm{kg}^{-1} \mathrm{~d}^{-1}$ as long as the units are consistent and clearly stated. Common vocabularies should be used in all metadatabases and data formats, following guideline established by the British Oceanographic Data Centre (BODC) by means of the National Environment Research Council (NERC) Vocabulary Server (NVS2.0). For instance, the following terms

\footnotetext{
${ }^{3}$ www.pangaea.de

${ }^{4}$ https://www.bco-dmo.org

${ }^{5}$ https://www.seadatanet.org/
}

were submitted to the NERC Vocabulary Server (NVS2.0) to facilitate future data archiving and search.

$\mathrm{N}_{2} \mathrm{OPR}=$ The production of nitrous oxide [ $\mathrm{N}_{2} \mathrm{O}$ CAS 1002497-2] per day per unit volume of the experiment water sample by ${ }^{15} \mathrm{~N}$ [ ${ }^{15} \mathrm{~N}$ CAS $14390-96-6$, CAS 68378-96-1, and CAS 31432-469] isotope labeled tracer addition, incubation and purge and trap measurement at the GC-IRMS.

$\mathrm{N}_{2} \mathrm{OCON}=$ The consumption of nitrous oxide $\left[\mathrm{N}_{2} \mathrm{O}\right.$ CAS 10024-97-2] per day per unit volume of the experiment water sample by ${ }^{15} \mathrm{~N} \quad\left[{ }^{15} \mathrm{~N}\right.$ CAS 10024-97-2] isotope labeled tracer addition, incubation and purge and trap measurement at the GC-IRMS.

Any available ancillary dataset (e.g., microbiological sequences) should also be mentioned in the metadata.

\section{CONCLUDING REMARKS}

We present protocols to measure nitrous oxide production and consumption rates. This approach takes advantage of the fact that ${ }^{15} \mathrm{~N}$ exists in low abundances in the natural environment. With recent advances in isotope ratio mass spectrometry, it is now possible to measure $\mathrm{N}_{2} \mathrm{O}$ isotopes down to nanomolar concentrations and detect $\mathrm{N}_{2} \mathrm{O}$ production rates as low as $0.001 \mathrm{nM} / \mathrm{d}$. Measuring actual process rates is essential to understand the environmental factors controlling $\mathrm{N}_{2} \mathrm{O}$ production and consumption in marine and freshwater environments.

While we present the different approaches currently used by experts in the field to measure $\mathrm{N}_{2} \mathrm{O}$ transformation rates, a thorough inter-comparison of these protocols between labs, as well as across larger spatial and temporal scales is undoubtedly the next step moving forward. This will require a community effort that is beyond the scope of this manuscript.

\section{DATA AVAILABILITY STATEMENT}

Publicly available datasets were analyzed in this study. The $\mathrm{N}_{2} \mathrm{O}$ production rate data from Frey et al. (2020) are available at: https://doi.pangeae/10.1594/PANGAEA.914948 and the $\mathrm{N}_{2} \mathrm{O}$ consumption rate data are available as part of the Supplementary Material in Sun et al. (2020).

\section{AUTHOR CONTRIBUTIONS}

$\mathrm{AB}$ and $\mathrm{CF}$ took the lead in writing the manuscript. $\mathrm{XS}, \mathrm{AJ}$, and LAB substantially helped to write section 2, Part B: Tracer incubations for $\mathrm{N}_{2} \mathrm{O}$ consumption. $\mathrm{CF}$ and $\mathrm{XS}$ provided the data presented in the results section. All authors provided critical feedback and helped write the manuscript.

\section{FUNDING}

The Lake Arrowhead workshop was organized by the Ocean Carbon and Biogeochemistry project office, which is supported 
by the US National Science Foundation (NSF, grant \#1558412) and the National Aeronautics and Space Administration (grant \#NNX17AB17G). This work was funded in part by support from the DOE Great Lakes Bioenergy Research Center (DOE BER Office of Science DE-SC0018409) to NO, NSF grant \#1657663 to CF, AJ, and BW, and NSF grant \#1927755 to AB.

\section{ACKNOWLEDGMENTS}

This manuscript is an outcome of the "Oceanic Methane and Nitrous Oxide Workshop: The present situation and future

\section{REFERENCES}

Babbin, A. R., Bianchi, D., Jayakumar, A., and Ward, B. B. (2015). Rapid nitrous oxide cycling in the suboxic ocean. Science 348, 1127-1129. doi: 10.1126/ science.aaa8380

Bender, M. L., Tans, P. P., Ellis, J. T., Orchardo, J., and Habfast, K. (1994). A high precision isotope ratio mass spectrometry method for measuring the $\mathrm{O}_{2} / \mathrm{N}_{2}$ ratio of air. Geochim. Cosmochim. Acta 58, 4751-4758.

Bergsma, T. T., Ostrom, N. E., Emmons, M., and Robertson, G. P. (2001). Measuring simultaneous fluxes from soil of $\mathrm{N}_{2} \mathrm{O}$ and $\mathrm{N}_{2}$ in the field using the ${ }^{15} \mathrm{~N}$-gas "non-equilibrium" technique. Environ. Sci. Technol. 35, 4307-4312. doi: $10.1021 / \mathrm{es} 010885 \mathrm{u}$

Bourbonnais, A., Juniper, S. K., Butterfield, D. A., Devol, A. H., Kuypers, M. M. M., Lavik, G., et al. (2012). Activity and abundance of denitrifying bacteria in the subsurface biosphere of diffuse hydrothermal vents of the Juan de Fuca Ridge. Biogeosci. Dis. 9, 4661-4678. doi: 10.5194/bg-9-4661-2012

Bourbonnais, A., Letscher, R. T., Bange, H. W., Echevin, V., Larkum, J., Mohn, J., et al. (2017). $\mathrm{N}_{2} \mathrm{O}$ production and consumption from stable isotopic and concentration data in the Peruvian coastal upwelling system. Global Biogeochem. Cycles 31, 678-698. doi: 10.1002/2016gb005567

Braman, R. S., and Hendrix, S. A. (1989). Nanogram nitrite and nitrate determination in environmental and biological materials by vanadium (III) reduction with chemiluminescence detection. Anal. Chem. 61, 2715-2718. doi: 10.1021/ac00199a007

Bulow, S. E., Rich, J. J., Naik, H. S., Pratihary, A. K., and Ward, B. B. (2010). Denitrification exceeds anammox as a nitrogen loss pathway in the Arabian Sea oxygen minimum zone. Deep Sea Res. Part I 57, 384-393. doi: 10.1016/j.dsr. 2009.10.014

Casciotti, K. L., Forbes, M., Vedamati, J., Peters, B. D., Martin, T. S., and Mordy, C. W. (2018). Nitrous oxide cycling in the Eastern Tropical South Pacific as inferred from isotopic and isotopomeric data. Deep Sea Res. Part II: Top. Stud. Oceanography 156, 155-167. doi: 10.1016/j.dsr2.2018.07.014

Charoenpong, C. N., Bristow, L. A., and Altabet, M. A. (2014). A continuous flow isotope ratio mass spectrometry method for high precision determination of dissolved gas ratios and isotopic composition. Limnol. Oceanography: Methods 12, 323-337. doi: 10.4319/lom.2014.12.323

Dalsgaard, T., Stewart, F. J., Thamdrup, B., De Brabandere, L., Revsbech, N. P., Ulloa, O., et al. (2014). Oxygen at nanomolar levels reversibly suppresses process rates and gene expression in anammox and denitrification in the oxygen minimum zone off northern Chile. mBio 5:e01966.

Dalsgaard, T., Thamdrup, B., Farías, L., and Revsbech, N. P. (2012). Anammox and denitrification in the oxygen minimum zone of the eastern South Pacific. Limnol. Oceanogr. 57, 1331-1346. doi: 10.4319/lo.2012.57.5.1331

De Brabandere, L., Thamdrup, B., Revsbech, N. P., and Foadi, R. (2012). A critical assessment of the occurrence and extend of oxygen contamination during anaerobic incubations utilizing commercially available vials. J. Microbiol. Methods 88, 147-154. doi: 10.1016/j.mimet.2011.11.001

Devol, A. H., Uhlenhopp, A. G., Naqvi, S. W. A., Brandes, J. A., Jayakumar, D. A., Naik, H., et al. (2006). Denitrification rates and excess nitrogen gas concentrations in the Arabian Sea oxygen deficient zone. Deep Sea Res. Part I: Oceanograph. Res. Papers 53, 1533-1547. doi: 10.1016/j.dsr.2006.07.005 scenarios!" at Lake Arrowhead in October 2018. We would like to thank all participants for engaging in fruitful and constructive discussions during the workshop. We would also like to thank Colette Kelly, two reviewers and guest associate editor Johannes Karstensen for their constructive comments.

\section{SUPPLEMENTARY MATERIAL}

The Supplementary Material for this article can be found online at: https://www.frontiersin.org/articles/10.3389/fmars. 2021.611937/full\#supplementary-material

Emerson, S., Stump, C., Wilbur, D., and Quay, P. (1999). Accurate measurement of $\mathrm{O}_{2}, \mathrm{~N}_{2}$, and Ar gases in water and the solubility of $\mathrm{N}_{2}$. Mar. Chem. 64, 337-347. doi: 10.1016/s0304-4203(98)00090-5

Frame, C. H., Lau, E., Nolan, E. J. IV, Goepfert, T. J., and Lehmann, M. F. (2017). Acidification enhances hybrid $\mathrm{N}_{2} \mathrm{O}$ production associated with aquatic ammonia-oxidizing microorganisms. Front. Microbiol. 7:2104. doi: 10.3389/ fmicb.2016.02104

Frey, C., Bange, H. W., Achterberg, E. P., Jayakumar, A., Löscher, C. R., ArévaloMartínez, D. L., et al. (2020). Regulation of nitrous oxide production in low-oxygen waters off the coast of Peru. Biogeosciences 17, 2263-2287. doi: 10.5194/bg-17-2263-2020

Fuchsman, C. A., Devol, A. H., Saunders, J. K., McKay, C., and Rocap, G. (2017). Niche partitioning of the $\mathrm{N}$ cycling microbial community of an offshore oxygen deficient zone. Front. Microbiol. 8:2384. doi: 10.3389/fmicb.2017. 02384

Ganesh, S., Parris, D. J., DeLong, E. F., and Stewart, F. J. (2014). Metagenomic analysis of size-fractionated picoplankton in a marine oxygen minimum zone. ISME J. 8, 187-211. doi: 10.1038/ismej.2013.144

Garcia-Robledo, E., Borisov, S., Klimant, I., and Revsbech, N. P. (2016). Determination of respiration rates in water with sub-micromolar oxygen concentrations. Front. Mar. Sci. 3:244. doi: 10.3389/fmars.2016.00244

Holtappels, M., Lavik, G., Jensen, M. M., and Kuypers, M. M. (2011). ${ }^{15}$ N-labeling experiments to dissect the contributions of heterotrophic denitrification and anammox to nitrogen removal in the OMZ waters of the ocean. Methods Enzymol. 486, 223-251. doi: 10.1016/b978-0-12-381294-0.00010-9

Huang, Y., Xiao, X., and Long, X. (2017). Fungal denitrification contributes significantly to $\mathrm{N}_{2} \mathrm{O}$ production in a highly acidic tea soil. J. Soils Sediments 17, 1599-1606. doi: 10.1007/s11368-017-1655-y

Ji, Q., Babbin, A. R., Jayakumar, A., Oleynik, S., and Ward, B. B. (2015). Nitrous oxide production by nitrification and denitrification in the Eastern Tropical South Pacific oxygen minimum zone. Geophys. Res. Lett. 42, 10-755.

Kalvelage, T., Lavik, G., Lam, P., Contreras, S., Arteaga, L., Löscher, C. R., et al. (2013). Nitrogen cycling driven by organic matter export in the South Pacific oxygen minimum zone. Nat. Geosci. 6, 228-234. doi: 10.1038/ngeo1739

Kana, T. M., Darkangelo, C., Hunt, M. D., Oldham, J. B., Bennett, G. E., and Cornwell, J. C. (1994). Membrane inlet mass spectrometer for rapid highprecision determination of $\mathrm{N}_{2}, \mathrm{O}_{2}$, and $\mathrm{Ar}$ in environmental water samples. Anal. Chem. 66, 4166-4170. doi: 10.1021/ac00095a009

Kozlowski, J. A., Kits, K. D., and Stein, L. Y. (2016). Comparison of nitrogen oxide metabolism among diverse ammonia-oxidizing bacteria. Front. Microbiol. 7:1090. doi: 10.3389/fmicb.2016.01090

Larsen, M., Lehner, P., Borisov, S. M., Klimant, I., Fischer, J. P., Stewart, F. J., et al. (2016). In situ quantification of ultra-low $\mathrm{O}_{2}$ concentrations in oxygen minimum zones: application of novel optodes. Limnol. Oceanography: Methods 14, 784-800. doi: 10.1002/lom3.10126

McIlvin, M. R., and Altabet, M. A. (2005). Chemical conversion of nitrate and nitrite to nitrous oxide for nitrogen and oxygen isotopic analysis in freshwater and seawater. Anal. Chem. 77, 5589-5595. doi: 10.1021/ac050528s

McIlvin, M. R., and Casciotti, K. L. (2010). Fully automated system for stable isotopic analyses of dissolved nitrous oxide at natural abundance levels. Limnol. Oceanography: Methods 8, 54-66. doi: 10.4319/lom.2010.8.0054 
Myhre, G., Shindell, D., Breìon, F.-M., Collins, W., Fuglestvedt, J., Huang, J., et al. (2013). "Anthropogenic and natural radiative forcing," in Climate Change 2013: The Physical Science Basis. Contribution of Working Group I to the Fifth Assessment Report of the Intergovernmental Panel on Climate Change, eds T. F. Stocker, D. Qin, G.-K. Plattner, M. Tignor, S. K. Allen, J. Boschung, et al. (Cambridge: Cambridge University Press).

Nevison, C., and Holland, E. (1997). A reexamination of the impact of anthropogenically fixed nitrogen on atmospheric $\mathrm{N}_{2} \mathrm{O}$ and the stratospheric $\mathrm{O}_{3}$ layer. J. Geophys. Res.: Atmospheres 102, 25519-25536. doi: 10.1029/97jd02391

Nevison, C. D., Lueker, T. J., and Weiss, R. F. (2004). Quantifying the nitrous oxide source from coastal upwelling. Global Biogeochem. Cycles 18:GB1018 1-17.

Niemann, H., Steinle, L., Blees, J., Bussmann, I., Treude, T., Krause, S., et al. (2015). Toxic effects of lab-grade butyl rubber stoppers on aerobic methane oxidation. Limnol. Oceanography: Methods 13, 40-52. doi: 10.1002/lom3.1 0005

Ostrom, N. E., Gandhi, H., Trubl, G., and Murray, A. E. (2016). Chemodenitrification in the cryoecosystem of Lake Vida, Victoria Valley, Antarctica. Geobiology 14, 575-587. doi: 10.1111/gbi.12190

Padilla, C. C., Bristow, L. A., Sarode, N., Garcia-Robledo, E., Ramírez, E. G., Benson, C. R., et al. (2016). NC10 bacteria in marine oxygen minimum zones. ISME J. 10, 2067-2071. doi: 10.1038/ismej.2015.262

Piña-Ochoa, E., Høgslund, S., Geslin, E., Cedhagen, T., Revsbech, N. P., Nielsen, L. P., et al. (2010). Widespread occurrence of nitrate storage and denitrification among Foraminifera and Gromiida. Proc. Natl. Acad. Sci. U S A. 107, 11481153. doi: 10.1073/pnas.0908440107

Prosser, J. I, Hink, L., Gubry-Rangin, C., and Nicol, G. W. (2020). Nitrous oxide production by ammonia oxidizers: physiological diversity, niche differentiation and potential mitigation strategies. Global Change Biol. 26, 103-118. doi: 10. 1111 /gcb.14877

Ravishankara, A. R., Daniel, J. S., and Portmann, R. W. (2009). Nitrous oxide $\left(\mathrm{N}_{2} \mathrm{O}\right)$ : the dominant ozone-depleting substance emitted in the 21 st century. Science 326, 123-125. doi: 10.1126/science.1176985

Sharp, Z. (2017). Principles of Stable Isotope Geochemistry, 2nd Edn. Albuquerque: Open Educational Resources, University of New Mexico.

Shoun, H., Fushinobu, S., Jiang, L., Kim, S. W., and Wakagi, T. (2012). Fungal denitrification and nitric oxide reductase cytochrome P450nor. Philos. Trans. R. Soc. B: Biol. Sci. 367, 1186-1194. doi: 10.1098/rstb.2011.0335

Sigman, D. M., Casciotti, K. L., Andreani, M., Barford, C., Galanter, M. B. J. K., and Böhlke, J. K. (2001). A bacterial method for the nitrogen isotopic analysis of nitrate in seawater and freshwater. Anal. Chem. 73, 4145-4153. doi: 10.1021/ ac010088e
Stein, L. Y. (2019). Insights into the physiology of ammonia-oxidizing microorganisms. Curr. Opin. Chem. Biol. 49, 9-15. doi: 10.1016/j.cbpa.2018.09. 003

Stramma, L., Johnson, G. C., Sprintall, J., and Mohrholz, V. (2008). Expanding oxygen-minimum zones in the tropical oceans. Science 320, 655-658. doi: 10.1126/science. 1153847

Sun, X., Jayakumar, A., Tracey, J. C., Wallace, E., Kelly, C. L., Casciotti, K. L., et al. (2020). Microbial $\mathrm{N}_{2} \mathrm{O}$ consumption in and above marine $\mathrm{N}_{2} \mathrm{O}$ production hotspots. ISME J. doi: 10.1038/s41396-020-00861-2 [Epub ahead of print].

Trimmer, M., Chronopoulou, P. M., Maanoja, S. T., Upstill-Goddard, R. C., Kitidis, V., and Purdy, K. J. (2016). Nitrous oxide as a function of oxygen and archaeal gene abundance in the North Pacific. Nat. Commun. 7:13451.

Ward, B. B., Devol, A. H., Rich, J. J., Chang, B. X., Bulow, S. E., Naik, H., et al. (2009). Denitrification as the dominant nitrogen loss process in the Arabian Sea. Nature 461:78. doi: 10.1038/nature08276

Weigand, M. A., Foriel, J., Barnett, B., Oleynik, S., and Sigman, D. M. (2016). Updates to instrumentation and protocols for isotopic analysis of nitrate by the denitrifier method. Rapid Commun. Mass Spectrometry 30, 1365-1383. doi: $10.1002 / \mathrm{rcm} .7570$

Weiss, R. F., and Price, B. A. (1980). Nitrous oxide solubility in water and seawater. Mar. Chem. 8, 347-359. doi: 10.1016/0304-4203(80)90024-9

Wilson, S. T., Al-Haj, A. N., Bourbonnais, A., Frey, C., Fulweiler, R. W., Kessler, J. D., et al. (2020). Ideas and perspectives: a strategic assessment of methane and nitrous oxide measurements in the marine environment. Biogeosciences 17, 5809-5828.

Wilson, S. T., Bange, H. W., Arévalo-Martínez, D. L., Barnes, J., Borges, A. V., Brown, I., et al. (2018). An intercomparison of oceanic methane and nitrous oxide measurements. Biogeosciences 15, 5891-5907.

Zhu-Barker, X., Cavazos, A. R., Ostrom, N. E., Horwath, W. R., and Glass, J. B. (2015). The importance of abiotic reactions for nitrous oxide production. Biogeochemistry 126, 251-267. doi: 10.1007/s10533-015-0166-4

Conflict of Interest: The authors declare that the research was conducted in the absence of any commercial or financial relationships that could be construed as a potential conflict of interest.

Copyright (C) 2021 Bourbonnais, Frey, Sun, Bristow, Jayakumar, Ostrom, Casciotti and Ward. This is an open-access article distributed under the terms of the Creative Commons Attribution License (CC BY). The use, distribution or reproduction in other forums is permitted, provided the original author(s) and the copyright owner(s) are credited and that the original publication in this journal is cited, in accordance with accepted academic practice. No use, distribution or reproduction is permitted which does not comply with these terms. 